\title{
PRODUÇÃO E DECOMPOSIÇÃO DE SERAPILHEIRA EM UM TRECHO DA FLORESTA PLUVIAL ATLÂNTICA - ESTAÇÃO BIOLÓGICA DE BORACÉIA (SÃO PAULO - BRASIL)
}

\section{ALCEBIADES CUSTODIO FILHO \\ Biólogo}

Orientador: Prof. Dr. FÁBIO POGGIANI

Dissertação apresentada à Escola Superior de Agricultura "Luiz de Queiroz" da Universidade de São Paulo, para obtenção do título de Mestre em Ciências. Área de concentração Ciências Florestais.

PIRACICABA

Estado de São Paulo - Brasil

Novembro - 1994 
Ficha catalográfica preparada pela Seção de Livros da Divisão de Biblioteca e Documentação - PCLQ/USP

\section{Custodio Filho, Alcebiades}

C987p Produção e decomposição da serapilheira em um tre cho da Floresta Pluvial Atlántica - Estação Biológica de Boracéia (São Paulo - Brasil). Piracicaba, 1994. $68 p$. ilus.

Diss. (Mestre) - ESALQ

Bibliografia.

1. Biomassa florestal 2. Folhedo - Decomposição 3. Mata Atlāntica 4. Serapilheira - Produção 1. Escola Superior de Agricultura Luiz de Queiroz, Piracicaba

CDD $\quad 634.909816$ 


\section{PRODUÇÃO E DECOMPOSIÇÃO DE SERAPILHEIRA EM UM TRECHO DA FLORESTA PLUVIAL ATLÂNTICA - ESTAÇÃO BIOLÓGICA DE BORACÉIA (SÃO PAULO - BRASIL)}

Aprovado em : 16/12/1994.

Comissão julgadora :

Prof. Dr. Alvaro Fernando de Almeida ESALQ/USP

Prof. Dr. Fábio Poggiani ESALQ/USP

Prof. Dr. Quirino A. de C. Carmello

ESALQ/USP

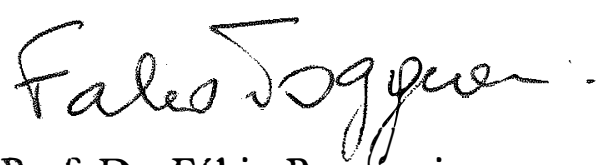

Prof. Dr. Fábio Poggiani

--- Orientador --. 
$\grave{A}$

Rita (un pup), por tudo

Ao

Leonardo (amigão) e Tanira (pretinha) por tantas alegrias 


\section{AGRADECIMENTOS}

Agradeço as pessoas e instituições que colaboraram, direta e indiretamente, para a execução deste trabalho, e especialmente:

A Oswaldo Handro e A.H. Gentry "in memoriam" mestres e amigos;

A Antonio Cecílio Dias, amigo de muitos trabalhos ;

Ao Instituto Florestal do Estado de São Paulo pela autorização da realização do curso;

Ao Prof. Dr. Fábio Poggiani pela orientação e amizade;

Ao Museu de Zoologia da Universidade de São Paulo, na pessoa de Dra. Francisca C. Val, pela autorização de uso da área e dos recursos da Estação Biológica de Boracéia e, pela amizada;

A Fundação de Amparo à Pesquisa do Estado de São Paulo, pelo auxílio concedido, para o desenvolvimento dos trabalhos de campo e de laboratorio, proc.85-1774-8;

Ao Conselho Nacional de Desenvolvimento Científico e Tecnológico pelo auxílio e bolsa concedidos, proc.301123/85 e 404369/85;

A CAPES (Coordenação de Aperfeiçoamento Científico e Tecnológico de Ensino Superior) pela bolsa concedida no período do curso e de análise de dados e redação;

Ao Senhor Firmino Rodrigues Gomes, encarregado da Estação Biológica, e companheiro nos trabalhos de campo; 
A Geraldo Antonio Daher Corrêa Franco pela contribuicão na excussão deste trabalho;

Aos companheiros e amigos de viagens e responsáveis pela descontração nas horas de trabalho e, principalmente nas conversas das horas de descanço: Sérgio Romaniuc Neto, Cibele Boni de Toledo, e João Dercílio, todos do Instituto de Botânica.

Ao Centro de Tecnologia e Hidraulica, do Departamento de Aguas e Energia Elétrica, na pessoa da Pesquisadora Kikuko Abe, pelo fornecimento dos dados hidrometereologicos e pela amizade.

À Pesquisadora Elvira Neves Domingues pelas leituras, sugestões e orientações em diferentes etapas deste, como em tantos outros trabalhos.

Aos Drs Hermogenes de Freitas Leitão Filho e Fernando Roberto Martins, pelas sujestões e incentivo, na implantação deste trabalho.

À Pesquisadora Marlene F. Tabanez, da E.E. de Assis, pela sensibilidade e ajuda. 


\section{SUMÁRIO}

Lista de Figuras ................................................................. vi

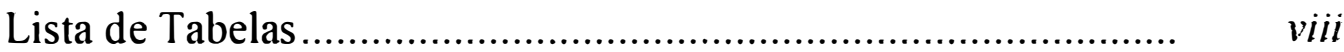

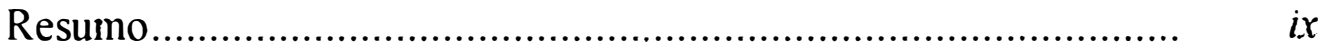

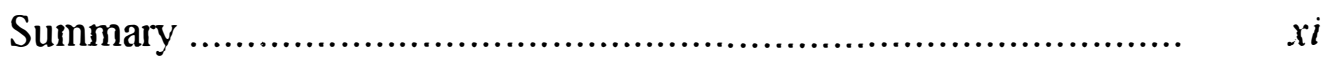

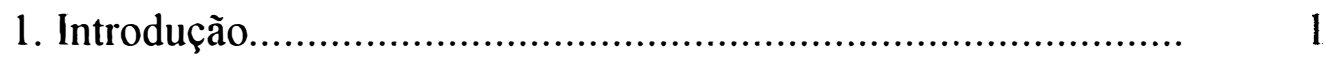

2. Revisão Bibliográfica.................................................... 3

2.1. A Floresta Pluvial Atlântica ............................................ 3

2.2. A deposição de Serapilheira ............................................... 6

3. Material e Métodos .......................................................... 10

3.1. A Estação Biológica de Boracéia ..................................... 10

3.1.1. A vegetação ........................................................ 14

3.1.2. Clima ........................................................... 17

3.1.3. Geomorfologia e Solos...................................... 18

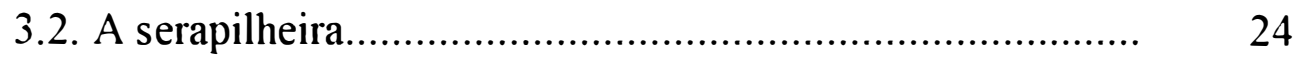

3.2.1. Trabalho de Campo................................................ 24

3.2.2. Métodos de Laboratório ....................................... 25

3.2.3. Análises Químicas .............................................. 26

3.2.4. Serapilheira Acumulada e Decomposição................ 26

4. Resultados e Discussão ........................................................ 28

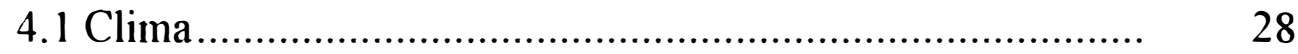

4.2. Deposição de Serapilheira ................................................ 32

4.3. Transferência de nutrientes ............................................. 48

4.4. Serapilheira acumulada e decomposição ........................... 54

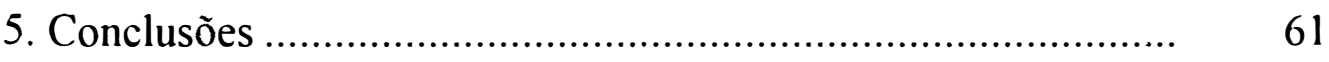

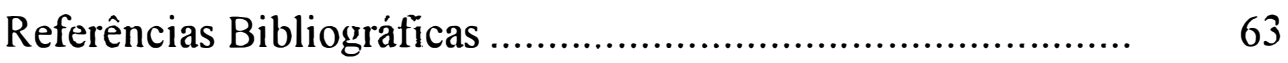




\section{LISTA DE FIGURAS}

Figura 1. Localização da Estação Biológica de Boracéia/SP............ 11

Figura 2. $\quad$ Aspecto aéreo da vegetação ................................................. 12

Figura 3. Folha topográfia .......................................................... 13

Figura 4. Vista aérea da vegetação da Estação Biológica de Boracéia .................................................................. 16

Figura 5. Temperaturas médias e, máximas e mínimas absolutas ....... 22

Figura 6. Climadiagrama para a região da Estação Biológica de Boracéia ..................................................................... 23

Figura 7. Valores mensais de pluviosidade..................................... 30

Figura 8. Valores mensais das temperaturas médias.......................... 31

Figura 9. Valores de umidade relativa ….................................... 33

Figura 10. Horas de sol ......................................................... 34

Figura 11. Valores médios das frações da serapilheira produzida ....... 41

Figura 12. Serapilheira e frações produzidas em dois anos ................ 43

Figura 13. Serapilheira e fraçòes produzidas. em dois anos................ 44

Figura 14. Variações de concentrações dos nutrientes, em relação a pluviosidade e a temperatura ......................................... 52

Figura 15. Variações de concentrações dos nutrientes, em relação à pluviosidade e à temperatura 
Figura 16. Tempo de desaparecimento da serapilheira .................... 57

Figura 17. Teores dos nutrientes na decomposiçào do folhedo .......... 60 


\section{LISTA DE TABELAS}

Tabela 1. Médias mensais, desvio padrão (dp), amplitude de variação e freqüuência das chuvas...................................... 19

Tabela 2. Valores de umidade relativa e insolação .............................. 20

Tabela 3. Médias das temperaturas médias, máximas e mínimas, e valores máximos e mínimos............................................ 21

Tabela 4. Análises quuímicas do solo ................................................ 24

Tabela 5. Valores mensais médios de temperatura, insolação e umidade relativa e total anual da pluviosidade ................ 29

Tabela 6. Produção mensal da serapilheira........................................ 36

$\begin{array}{lll}\text { Tabela 7. Serapilheira produzida em florestas tropicais brasileiras... } & 37\end{array}$

Tabela 8. Produçăo por fraçăo e total, em kg.ha-1, de serapilheira .. 40

Tabela 9. Produção por fração de serapilheira ao longo de dois anos de observações ....................................................... 42

Tabela 10. Coeficiente de correlação de Pearson .................................. 49

Tabela 11. Concentração dos macronutrientes, em porcentagem, por fração ................................................................... 51

Tahela 11. Valores dos macronutrientes, em $\mathrm{kg} \cdot \mathrm{ha}^{-1}$, por fração e total médio .................................................................. 51 


\title{
PRODUÇÃO E DECOMPOSIÇÃO DE SERAPILHEIRA EM UM TRECHO DA FLORESTA PLUVIAL ATLÂNTICA - ESTACÃO BIOLÓGICA DE BORACÉlA (SÃO PAULO - BRASIL)
}

\author{
Autor: ALCEBIADES CUSTODIO FILHO \\ Orientador: Prof. Dr. FÁBIO POGGIANI
}

\section{RESUMO}

Estudou-se, na Estação Biológica de Boracéia, durante 24 meses, a produção de serapilheira, avaliando-se a participaçào percentual apresentada pelas diferentes fraçòes que a compõem. Neste estudo, optou-se em dividir a serapilheira nas frações folhas, ramos e outros componentes tais como flores, frutos, sementes, etc.

A produçào mensal da serapilheira foi correlacionada com dados de pluviosidade, temperatura, umidade relativa e horas de insolação.

Foram ainda observados os valores de decomposiçào das folhas e estimado o tempo médio para o desaparecimento da serapilheira, e a taxa instatânea de decomposição.

Os resultados demonstraram que o clima é úmido, com temperaturas amenas, não ocorrendo déficit hídrico, sendo o solo ácido e de baixa fertilidade.

A produção anual da serapilheira foi de $6.054,10 \mathrm{~kg} \cdot \mathrm{ha}^{-1}$, onde a fraçào folhas contribuiu com $72,73 \%$; ramos com $16,09 \%$ e outros componentes 
com $11.29 \%$. Esses valores estão um pouco abaixo vdos padrões de produção encontrados em outras florestas tropicais. A produção mensal da serapilheira apresentou sazonalidade inconspícua; a constante de decomposição $\mathrm{K}$ foi estimada em 1,91, resultando em 0,52 anos ou 189 dias como tempo médio de renovação da serapilheira. O tempo necessário para o desaparecimento de $50 \%$ e $95 \%$ da serapilheira foi, respectivamente, de 131 e 573 dias.

As concentrações de macronutrientes das folhas caducas corresponderam a; $\mathrm{N}=1,73 \% ; \mathrm{P}=0,06 \% ; \mathrm{K}=0,26 \% ; \mathrm{Ca}=0,54 \% ; \mathrm{Mg}=0,23 \%$ e $S=0,18 \%$ e a transferência média de nutrientes via serapilheira, em kg.ha-1.ano-1, foi de 105,24 de N; 3,41 de P; 14,76 de K; 32,83 de Ca; 14,72 de $\mathrm{Mg}$ e 11.69 de S. 
LITTER PRODUCTION AND DECOMPOSITION IN THE ATLANTIC RAIN

\author{
FOREST - BORACEIA BIOLOGICAL STATION
}

(SÃO PAULO - BRAZIL)

\author{
Author: ALCEBIADES CUSTODIO FILHO \\ Adviser: Prof. Dr. FÁBIO POGGIANI
}

\title{
SUMMARY
}

This study is an analyses of litter production and decomposition, based on data collected in the Boraceia Biological Station from 1985 to 1987 (during 24 months). The litter was separated to leaves, branchs and other parts like flowers, fruits, seeds, etc. The percentage of each was rated.

The litter's monthly decomposition was correlated with weather data (rain, temperature, relative moisture and daily time radiation).

Leaves decomposition rate, estimated litter loss average time and the decomposition decay parameters were investigate.

Data showed high humidity, moderate temperature, no hydric deficit and acid soils with poor fertility levels.

The annual litter production is $6054.10 \mathrm{~kg} \cdot \mathrm{ha}^{-1}$ with the leaves fraction contributes $72.73 \%$ : branches $16.09 \%$ and the other parts $11.29 \%$. These values are below average levels for tropical forests. The monthly litter production does not show sharp change with the seasons. The computed decomposition constant $\mathrm{K}$ is 1.91 , wich means 0.52 years or 189 days average litter renovation 
time. The necessary time for $50 \%$ and $95 \%$ litter decomposition is 131 and 573 days, respectively.

Nutrient concentration in fallen leaves is: $N=1.73 \% ; \quad P$ $=0.06 \% ; \mathrm{K}=0.26 \%: \mathrm{Ca}=0.54 \% ; \mathrm{Mg}=0.23 \%$ and $\mathrm{S}=0.18 \%$ and the nutrient average translocated by litter, in $\mathrm{kg} \mathrm{ha}^{-1} \cdot \mathrm{yr}^{-1}$, is 105.24 for $\mathrm{N} ; 3.41$ for $\mathrm{P} ; 14.76$ for $\mathrm{K} ; 32.83$ for $\mathrm{Ca}: 14.72$ for $\mathrm{Mg}$ and 11.69 de $\mathrm{S}$. 


\section{INTRODUÇÃO}

A cobertura florestal, que originalmente existia no Estado de São Paulo, ocupando grande parte de seu território, está reduzida, no planalto paulista, a poucos fragmentos e, na costa litorânea, à floresta pluvial atlântica, que ocorre ao longo da costa oceânica e sobre os maciços montanhosos das Serras do Mar e de Paranapiacaba.

Atualmente, a floresta pluvial atlântica, é a maior e a mais importante expressão florestal existente no Estado, ocorrendo do extremo norte ao extremo sul, ao longo da região litorânea. Pela extensão e pelas diferentes condições edafo-climáticas que apresenta, abriga um grande número de espécies vegetais e animais e. como conseqüència dessas características, apresenta um grande número de espécies endèmicas. Todavia, essa vegetação carece de infornações quanto à sua composição, estrutura e dinâmica, embora vários trabalhos tenham sido realizados ou estejam em desenvolvimento. Contudo, considera-se a extensão e a complexidade dessa formação vegetal, como os fatores responsáveis pela escassez de dados, o que difículta um conhecimento mais profundo.

Além disso, estudos dessa natureza são necessários porque a floresta pluvial atlântica possui uma cobertura vegetal de importância vital na estabilidade das vertentes serranas e na biodiversidade que resguarda. Tal 
cobertura vem sendo descaracterizada, desde a ocupação do planalto paulista pelos colonizadores, atividade essa acentuada a partir da década de 50 , principalmente, devido aos processos industriais e ao uso inadequado dos recursos florestais.

Em relação aos ciclos biogeoquímicos, poucos trabalhos foram realizados na área de abrangência dessa vegetação. Sabe-se que o estudo da deposição e da decomposição de serapilheira, constituida pelo matérial decíduo como folhas, ramos, flores e frutos dos vegetais, é de grande importância, para a compreensão do ciclo biogeoquimico de um ecossistema florestal.

Esses dados aliados a outros, referentes aos estudos florísticos, proporcionarão um melhor embasamento para a tomada de decisões sobre o manejo que poderá ser dado à floresta pluvial atlântica.

A importância dessa vegetação e a necessidade de se conhecer, com maior detalhamento, os processos que regem seu equilibrio dinâmico justificam, portanto, o estudo da deposição e decomposição de serapilheira nesse ecossistema.

Esse trabalho teve como objetivos:

- estimar a deposição de serapilheira;

- estimar o retorno de nutrientes da fitomassa

arbórea para o solo, através da deposição

de serapilheira:

- estabelecer as correlações entre as condições

climáticas e a deposição de serapilheira, e

- observar a velocidade de decomposição do folhedo. 


\section{REVISÃO BIBLIOGRÁFICA}

\subsection{A Floresta Pluvial Atlântica}

Essa vegetação é constituída por florestas perenifólias latifoliadas higrófilas costeiras com fisionomia e florística bastante semelhante à da floresta amazônica, diferindo dela tanto mais quanto mais distante do equador (CAMPOS, 1912; ANDRADE-LIMA, 1966).

ROMARIZ (1972) ressalta que os componentes da floresta pluvial atlântica têm folhas largas, apresentam grande densidade arbórea e que a elevada umidade, garante seu caráter de vegetação perenifólia.

VELOSO e KLEIN (1957) denominam de Mata Pluvial às florestas da encosta atlântica que se distribuem desde o estado da Bahia até às estepes do Rio Grande do Sul.

COUTINHO (1962) ressalta que as árvores são distribuídas em dois ou mais estratos, sendo que, o superior pode atingir até $30 \mathrm{~m}$. Ocorrem muitas epífitas e trepadeiras, o solo é recoberto por inúmeras plantas herbáceas, com grande densidade vegetal. 
WESTTSTEIN (1970) assinala que o solo é revestido, principalmente, em barrancos úmidos, por musgos e hepáticas. Nas partes menos encharcadas, esse solo é coberto por serapilheira, onde ocorrem muitos fungos.

CAMPOS (1912) inforna que a grande diversidade biológica dessa vegetação é devida, principalmente, ao fato de sua grande extensão de ocorrência, entre as latitudes de $5^{\circ}$ e $30^{\circ} \mathrm{Sul}$, e do relevo muito acidentado.

FERRI (1980) aponta que a floresta pluvial atlântica é formada por ecossistemas extremamente complexos, com um número muito grande de nichos ecológicos. Graças à densidade da vegetação arbórea, o subosque é escuro, mal ventilado e úmido. Há no solo muita serapilheira, que origina abundante húmus. Assim, o ciclo planta-solo, explica a manutenção de florestas exuberantes, em solos nem sempre férteis, às vezes paupérrimos.

HUECK (1953) informa que a pujança dessa vegetação, devese à abundância das precipitações. e na ausência dessas, reina sempre grande umidade devido à condensação do vapor oriundo do oceano.

LEITÃO FILHO (1982 e 1987) afirma que, dessa formação existem apenas manchas disjuntas de vegetação e, que esse ecossistema foi duramente alterado sem ser conhecido. Sua grande diversidade florística deve-se às variações climáticas.

JOLY (1970) diz que os ventos úmidos que sopram do mar, ao subirem a escarpa atlântica, resfriam-se e não contendo o excesso de umidade, ocorre condensação e precipitação, principalmente nas partes mais altas da serra, em forma de nevoeiro ou chuva. Assim, a umidade sustenta a floresta costeira.

SILVA \& LEITÃO FILHO (1982) informam sobre a pobreza do solo da vegetação atlântica, caráter esse, que associado ao relevo e ao clima 
torna-a uma formação muito diversificada em espécies, todavia muito instável quanto ao equilíbrio dinâmico.

GOLLEY et al. (1978) observam que os solos das florestas tropicais são, na grande maioria, pobres e freqüentemente intemperizados a grandes profundidades, e que a perda de nutrientes por lixiviação é acelerada pelos altos indices pluviométricos. Observam, todavia, que essas florestas são muito sensiveis a déficits de nutrientes.

O clima da floresta pluvial atlântica no estado de São Paulo é classificado, segundo KOEPPEN (1948), como Af "tropical chuvoso com chuvas o ano todo"; e segundo NIMER (1977) como "super úmido sem seca" . Não existindo seca ecológica nessa região (COUTINHO, 1962), mesmo na ausência de chuvas, reina grande umidade pela condensação dos vapores oriundos do oceano (HUECK, 1953), com ocorrência de geadas em seu extremo sul (LEITÃO FILHO, 1987).

SETZER (1946) e CAMARGO (1972)*, citado por MEGURO (1987) relatam dois tipos climáticos segundo KOEPPEN (1948), influenciando a floresta pluvial atlântica: o tipo Af, na vertente voltada para a planície litorânea, e os tipos $\mathrm{Cfa}$ e $\mathrm{Cfb}$, na vertente voltada para o planalto.

Os indices pluviométricos são elevados e constantes durante todo ano, (MATTOS FILHO, 1930; JOLY, 1970 e AB'SABER, 1987).

* CAMARGO, J.G.C. Estudo fitogeográfico e ecológico da bacia hidrográfica paulista do Rio Ribeira, Biogeografia, São Paulo, 5: 1 - 30, 1972. 


\subsection{A Deposição de Serapilheira}

A serapilheira, também conhecida como liteira ou manta, é um dos compartimentos do ciclo de nutrientes. O material que forma a serapilheira do solo sob a floresta é uma mistura de vários componentes da estrutura das plantas: folhas, ramos, galhos, troncos e resíduos não identificáveis (MASON, 1980).

MEGURO et al. (1979) e PAGANO (1985) dizem que, no âmbito do estudo da ciclagem de nutrientes, a deposição do folhedo e o processo de decomposição constituem partes importantes e mais acessiveis da trajetória dos nutrientes no setor biológico e seu ambiente imediato, constituindo os compartimentos planta-folhedo-solo. A ordem de grandeza da restituição, e a velocidade com que ela se processa, estão relacionadas com a produtividade e com a capacidade de regeneração do ecossistema.

DELITTI (1984) infere, que o conhecimento das transformações que ocorrem no compartimento da serapilheira acumulada sobre $o$ solo das florestas são importantes para a compreensão da reciclagem de nutrientes e a dinâmica desses ecossistemas. Realça, que a deposição e a decomposição da serapilheira e a transferência de nutrientes liberados através desses processos, são os aspectos mais estudados dos ciclos biogeoquímicos.

GOLLEY et al. (1978) referem-se que, tais estudos, ao lado daqueles relativos ao fluxo de energia, são fundamentais para o conhecimento das 
caracteristicas funcionais dos ecossistemas e, por conseguinte, de sua resistência aos diversos fatores de tensão, decorrentes principalmente da atividade humana.

GOSZ et al. (1972) relatam que as florestas pluviais tropicais, ainda sào pouco conhecidas quanto à dinâmica dos nutrientes na superfície do solo.

SILVA (1984) diz que a deposição de serapilheira e a ciclagem de nutrientes estão ligadas às condições dos ecossistemas florestais.

KIMMINS (1987) definiu o processo de deposição de um ecossistema como o incremento de matéria orgânica por unidade de área numa unidade de tempo. Considera três ciclos de nutrientes na natureza: aquele que se processa entre ecossistemas - geoquímico: o que se processa dentro do ecossistema - biogeoquímico; e o ciclo na planta: bioquímico.

No Brasil, os estudos dos ciclos biogeoquímicos iniciaram-se na década de 60 , com os trabalhos desenvolvidos na regiào Amazônica por KLINGE \& RODRIGUES (1968 a e b), seguidos por KLINGE (1977), LUIZÃO (1982), SILVA \& LOBO (1982) e SILVA (1984). Estes aspectos, nas formações de cerrado, foram estudados por RIZZO et al. (1971), CARPANEZZI (1980) e DELITTI (1984). RIZZO et al. (1971) comparam em Goiás, os aspectos fenológicos da deposição da serapilheira num cerrado e em uma mata caducifólia tropical de planalto, detectando sazonalidade na deposição de folhas, no período de menores precipitações pluviométricas que para essas regiões correspondem ao inverno.

Para as plantações florestais, POGGIANI (1976), POGGIANI et al. (1979), CARPANEZZI (1980), GARRIDO (1981) e DELITTI (1984) avaliaram a deposição, a decomposição, a existência de sazonalidade e a 
concentração de nutrientes na serapilheira, em diferentes espécies. em plantios homogêneos. correlacionando esses dados com os obtidos para formações florestais nativas. GARRIDO (1981) desenvolveu, também, estudos comparando o comportamento silvicultural de espécies nativas do estado de São Paulo, em povoamentos puros e misto.

As florestas semidecíduas de planalto, foram objeto de estudo de MEGURO et al. (1979), PAGANO (1985), DINIZ (1987), MORELLATOFONZAR (1987), CESAR (1988), POGGIANI \& MONTEIRO JÚNIOR (1990) e SCHLITTLER (1990). MEGURO et al. (1979) coletaram o folhedo produzido em uma mata mesófila em São Paulo/SP. e analisaram a deposição da fração folhas que representou $62,6 \%$ do total de serapilheira. Detectaram a ocorrência de sazonalidade na deposição de folhedo, que estava associada às variações nos níveis pluviométricos, com a maior deposição ocorrendo na estação seca.

TEIXEIRA et al. (1992) estudaram uma floresta residual na periferia da cidade de São Paulo/SP. e observaram que os valores mensais médios da serapilheira produzida foram muito variáveis ao longo do ano, não encontrando relação entre deposição e precipitação pluviométrica.

POGGIANI \& MONTEIRO JÚNIOR (1990) estudaram a deposição de folhedo e o retorno de nutrientes ao solo, em uma vegetação de floresta estacional semidecídua em Piracicaba/SP. Observaram uma grande diferença de deposição de folhedo durante o ano, ressaltando que essa sazonalidade pode ser causada pelas variações climáticas, pela grande heterogeneidade do dossel e pelos diferentes estádios sucessionais.

JACKSON (1978), VARJABEDIAN \& PAGANO (1988), VUONO et al. (1989), DOMINGOS et al. (1990), TEIXEIRA et al. (1992) e 
LEITÃO FILHO et al. (1993) estudaram a floresta pluvial atlântica, em relação à composição florística e ciclagem de nutrientes.

JACKSON (1978) avaliou o estádio do conhecimento sobre os ecossistemas atlânticos, informando que os estudos multidisciplinares contribuirão decisivamente para a compreensão desse ecossistema. Alerta para o fato de que a deposição de serapilheira está associada às condições climáticas, correlacionadas, principalmente com a pluviosidade.

DOMINGOS et al. (1990) estudaram a ciclagem de nutrientes na reserva biológica de Paranapiacaba/SP., área sujeita à poluição atmosférica proveniente do Complexo Industrial de Cubatão, obtendo valores de deposição de serapilheira maiores para a área menos sujeita à poluição.

VARJABEDIAN \& PAGANO (1988), em estudo de deposição de folhedo na região de Guarujá/SP. na floresta pluvial atlântica, observaram que a fração folhas participou com a maior porcentagem $(63,6 \%)$. Os mais altos índices de deposição de serapilheira foram registrados nos meses de janeiro, fevereiro e outubro, não ocorrendo sazonalidade marcante.

VUONO et al. (1989) avaliaram a decomposição da serapilheira e a liberação de nutrientes na reserva biológica de Paranapiacaba/SP., em dois períodos distintos, não detectando sazonalidade na decomposição.

LEITÃO FILHO et al. (1993) estudando três áreas distintas da floresta atlântica em Cubatão/SP., constataram a ocorrência de variações na quantidade de folhedo produzido durante o ano, havendo igualmente, diferenças de deposição entre as áreas mais e menos poluídas. 


\section{MATERIAL E MÉTODOS}

\subsection{A Estação Biológica de Boracéia}

A Estação Biológica de Boracéia é localizada na serra do Mar, na vertente voltada para o planalto junto ao divisor marítimo, distando do mesmo apenas $1,5 \mathrm{Km}$ (figuras 1, 2 e 3), ela é conhecida na região como "Estação da Quina" e originou-se da antiga Estação Experimental do Instituto Agronômico de Campinas, que foi criada para o cultivo da quina (Chinchona ledgeriana R. \& P.), utilizada no combate à febre malárica. Passada a fase de cultivo, a Estação passou a ser administrada pelo Museu de Zoologia, da Universidade de São Paulo, na condição de Estação Biológica.

Ela abrange uma área de 805ha, do município de Salesópolis, Estado de São Paulo, nas coordenadas geográficas $23^{\circ} 38^{\prime}$ Latitude Sul e $46^{\circ} 32^{\prime}$ Longitude Oeste (figura 1), compõe parte da Reserva Florestal de Casa Grande, pertecente à Companhia de Saneamento Básico do Estado de São Paulo SABESP, criada com a função de proteção dos mananciais e a deposição de água. 


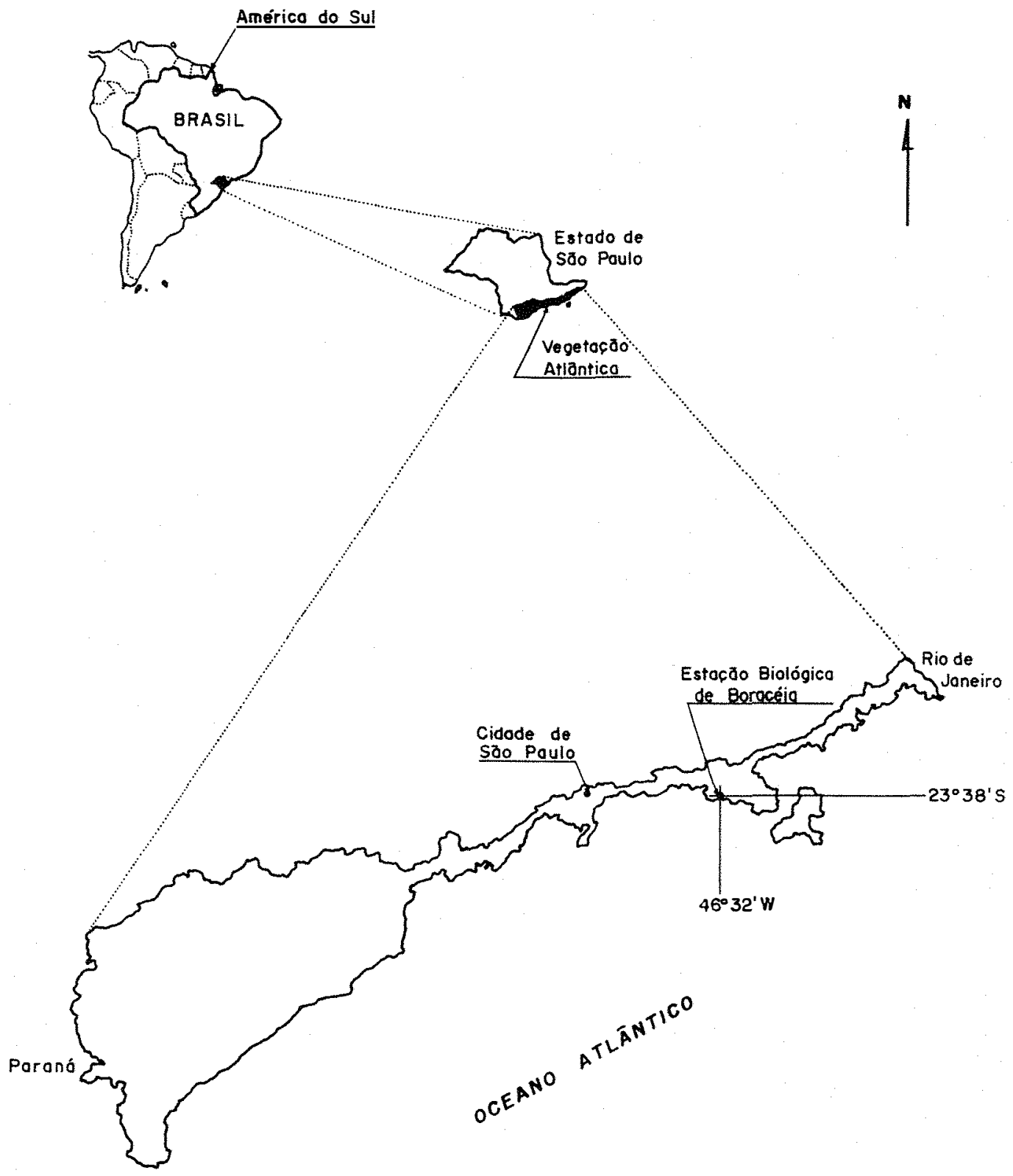

Figura 1. Localização da Estação Biológica de Boracéia/SP., dentro do contexto da vegetação Atlântica, São Paulo, Brasil. 


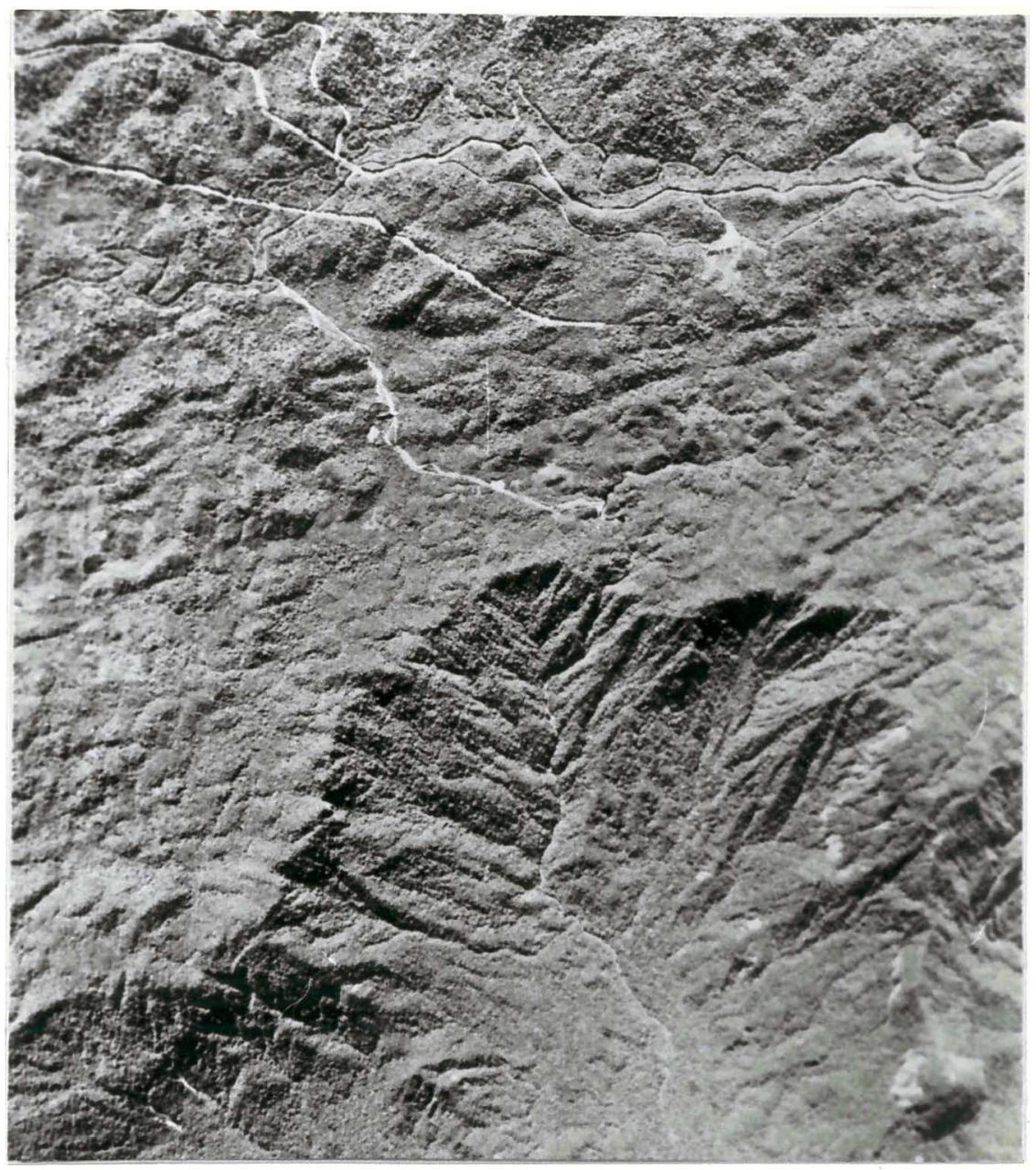

Figura 2. Aspecto aéreo da vegetação da Estação Biológica de Boracéia, e sua localização em relação ao divisor marítimo, a área pontilhada delimita o local de amostragem. (Foto aérea EMPLASA, Fx 10B. $451 / 77$, esc. 1:40.000). 


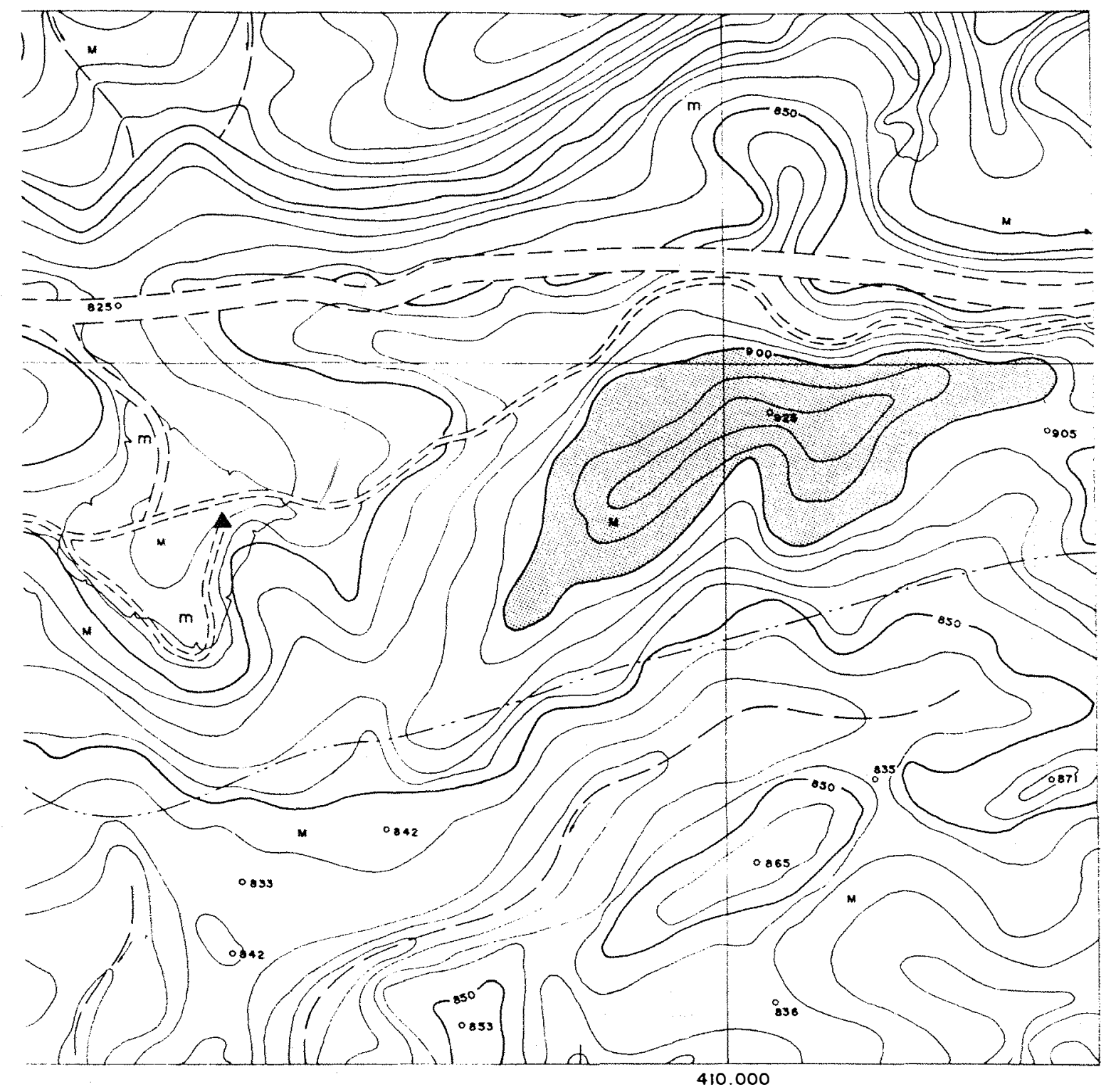

Figura 3. Área do experimento. em folha topográfia (escala 1:10.000). a área assinalada pelo triângulo corresponde o local do estudo. Estação Biológica de Boracéia/SP. 
Essa área está incluída, portanto, no Parque Estadual da Serra do Mar, unidade de conservação do Estado de São Paulo, administrada pelo Instituto Florestal de São Paulo, da Secretaria de Estado do Meio Ambiente e ocupa uma posição estratégica, por ser uma área naturalmente protegida, com poucos sinais de degradações. Apresenta grande interesse ecológico e social, pelas suas características vegetais e faunísticas, por compor parte da Reserva da Biosfera e pela captação de água para a Região da Grande São Paulo.

\subsubsection{A Vegetação}

A classificação definitiva da vegetação da Estação Biológica de Boracéia, toma-se difícil, dada à existência de diferentes sistemas, que adotam critérios específicos cada qual com sua proposta de classificação, embasados geralmente, no aspecto exclusivamente físionômico (FERRI, 1974 e SILVA \& LEITÃO FILHO, 1982).

WALTER (1977) classifica-a como floresta pluvial tropical sempre verde, onde as chuvas orográficas estão presentes. ROMARIZ (1972) reconhece-a como uma floresta latifoliada tropical úmida de encosta. Já VELOSO \& KLEIN (1957) denominam-na como mata pluvial. LEITÃO FILHO (1982 e 1987) e SILVA \& LEITÃO FILHO (1982) adotaram a denominação de mata atlântica; MUELLER-DOMBOIS \& ELLEMBERG (1974) dizem tratar-se de floresta ombrófila montana latifoliada. RIZZINI (1979) classifica-a como uma floresta montana, COUTINHO (1962) denomina-a floresta pluvial tropical e 
AB' SABER (1956) diz tratar-se de uma floresta pluvial atlântica.

Localizada na zona tropical, todavia muito próxima ao Trópico de Capricórnio e sob a influência da altitude, alterando as temperaturas e as precipitações pela interceptação dos ventos alísios, que sopram constantemente do oceano para o planalto. Essas condiçōes, segundo HOLDRIDGE (1978), condicionam uma floresta subtropical baixo-montana muito úmida.

Neste estudo adotou-se a classificação de floresta pluvial atlântica e reconhece-se que a vegetação da Estação Biológica de Boracéia é constituída por espécies de floresta pluvial tropical. Apresenta um denso dossel com árvores distribuídas em dois ou mais estratos, onde o dominante varia de 20 a 30m., com ocorrência de muitas epífitas, lianas e trepadeiras e solo recoberto por muitas herbáceas, musgos, hepáticas e fungos (figura 4).

Considerando tais características. CUSTODIO FILHO (1989) relatou para a área, 110 famílias e 480 espécies vegetais. ocorrendo, em número de espécies, o domínio das famílias Orchidaceae, Melastomataceae, Compositae, Solanaceae, Leguminosae e Myrtaceae, sendo a Euterpe edulis Mart., a espécie mais freqüente.

CUSTODIO FILHO et al. ${ }^{* *}$, em estudo fitossociológico, identificaram através do Índice de Valor de Importância (IVI), que as famílias mais importantes, na região de Boracéia, em ordem decrescente, são: Lauraceae, Palmae, Sapotaceae, Rubiaceae, Bombacaceae, Euphorbiaceae, Monimiaceae e Myrtaceae. As espécies mais importantes, através do mesmo índice (IVI), são: Euterpe edulis,

${ }^{* *}$ CUSTODIO FILHO, A.; NEGREIROS, O.C.; DIAS, A.C. \& FRANCO, G.A.D.C. Estrutura fitossociológica de um trecho da floresta pluvial atlântica, Estação Biológica de Boracéia. Revista do Instituto Florestal, São Paulo . 

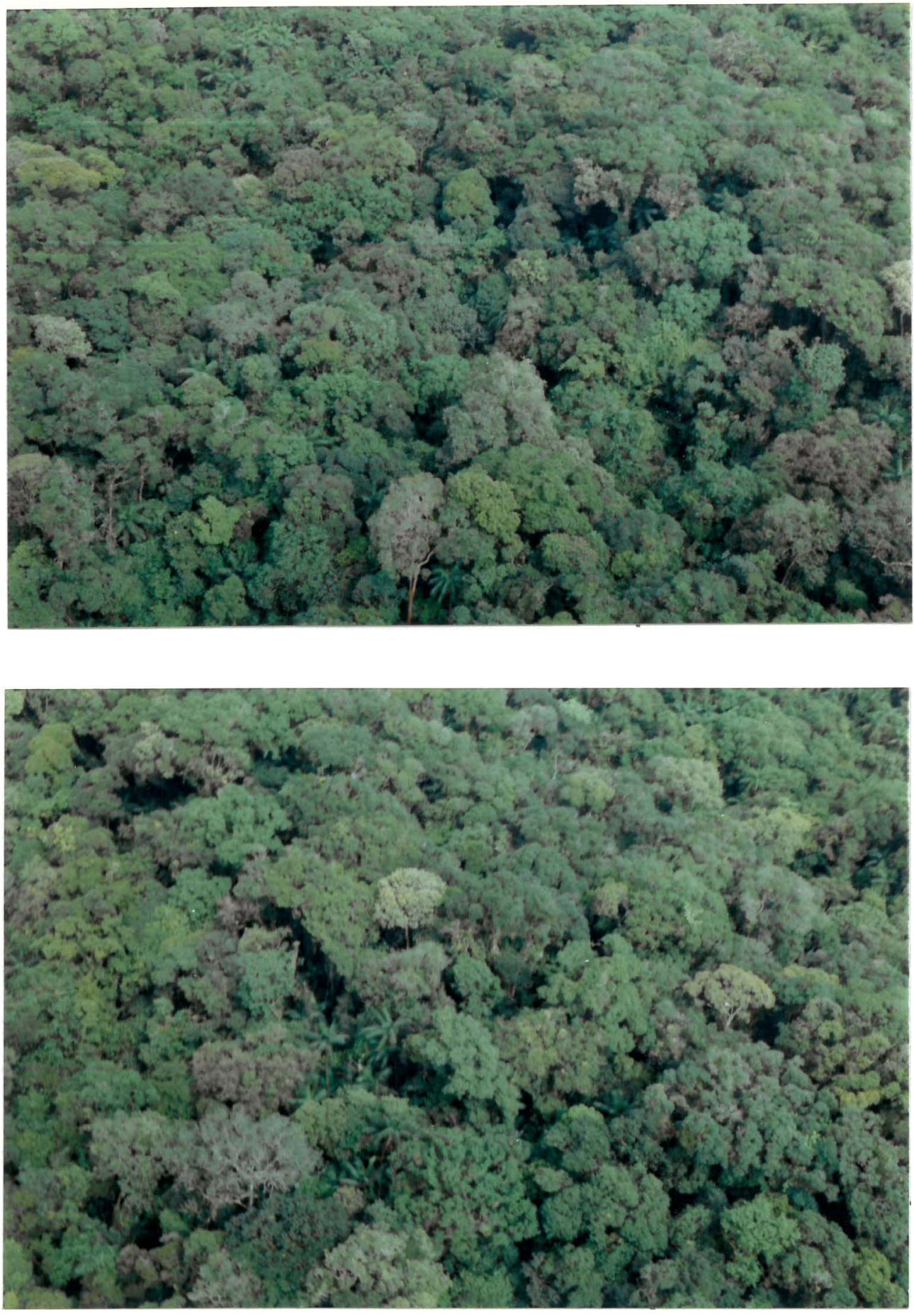

Figura 4. Vista aérea da vegetação da Estação Biológica de Boracéia/SP., mostrando a composição do dossel. 
Microphollis gardnerianum. Eriotheca pentaphylla, Bathysa meridionalis, Alchornea triplinervia, Hyeronima alchorneioides, Cryptocaria sp e Mollinedia sp. Obtiveram a distância média entre árvores como $3,47 \mathrm{~m}$, com uma amplitude que variava de $11,96 \mathrm{~m}$ a $0,21 \mathrm{~m}$. A circunferência (cap) média calculada foi de $0,76 \mathrm{~m}$ com valores máximo e mínimo de $3.72 \mathrm{~m}$ e $0,32 \mathrm{~m}$, respectivamente. A área basal total por hectare foi de $52,82 \mathrm{~m}^{2}$ e a altura média calculada atingiu $13.41 \mathrm{~m}$., com máximo em de $31 \mathrm{~m}$ e mínimo em $4 \mathrm{~m}$.

\subsubsection{CLIMA}

O clima da floresta pluvial atlântica na Estação Biológica de Boracéia classifica-se como Cfa, segundo KOEPPEN (1948).

A pluviosidade anual é de $2.504,8 \mathrm{~mm}$ (tabela 1). Os meses de maiores precipitações, os maiores índices de umidade relativa e insolação (tabela 2) ocorreram nos meses de maiores temperaturas (verão), estação das chuvas. A umidade relativa média anual é de $86 \%$. O inverno é pouco frio e moderadamente chuvoso.

A temperatura média anual é de $17,9^{\circ} \mathrm{C}$, a qual coloca a região de Boracéia como Subtropical, segundo a classificação de HOLDRIGDE (1978). O mês mais frio (julho) apresenta temperatura média de $14,7^{\circ} \mathrm{C}$, com mínima absoluta de $-2,6{ }^{\circ} \mathrm{C}$ e o mês mais quente (fevereiro), apresenta temperatura média de $21,5{ }^{\circ} \mathrm{C}$, com máxima absoluta de $34,9^{\circ} \mathrm{C}$ (tabela $3 \mathrm{e}$ figura 5). 
Para a caracterização climática e para a confeç̧ão do climadiagrama (fígura 6), de acordo com a metodologia proposta por WALTER (1984), foram utilizados os dados diários de pluviosidade, temperatura, umidade relativa do ar e insolação, obtidos no posto E2 - 110 (Casa Grande) do Centro de Tecnologia e Hidráulica (CTH), do Departamento de Águas e Energia Elétrica (D.A.E.E.), referentes ao período de 1953 a 1989.

\subsubsection{Geomorfologia e Solos}

A Estação Biológica de Boracéia, está localizada no Planalto Atlântico, zona do Planalto Paulistano e subzonas das Morrarias do Embu, onde o relevo é ondulado (morrotes baixos), com predomínio de amplitudes locais menores que 50m., topos arredondados, vertentes em perfis convexos a retilíneos (PONÇ.ANO et al., 1981).

Os solos são rasos e de origem granítica, com a presença freqüente de afloramentos rochosos, classificados como pertencentes ao tipo "Campos do Jordão e Litosol - fase substrato granito-gnaisse". São solos arenosos, ácidos, com altos teores de alumínio (BRASIL, 1960).

Para a caracterização edáfica da área do experimento, utilizaram-se amostras de solo, retiradas seguindo-se as recomendações do Instituto Agronômico de Campinas, nas profundidades $0-20 \mathrm{~cm}, 20-40 \mathrm{~cm}$ e $40-$ $60 \mathrm{~cm}$, as quais foram enviadas para as análises químicas, realizadas pelo mesmo Instituto (tabela 4). 
Tabela 1. Médias mensais, desvio padrão, amplitude de variação e freqüência das chuvas iguais ou maiores que $1 \mathrm{~mm}$., para a região da Estação Biológica de Boracéia/SP. Posto metereológico E2 110 do CTH - DAEE, período de 1953 a 1989.

P R E C I P I T A Ç Ã O

\begin{tabular}{|c|c|c|c|c|c|c|c|c|}
\hline \multirow[b]{2}{*}{ Mês } & \multicolumn{2}{|c|}{ Total } & \multicolumn{2}{|c|}{ Amplitude } & \multicolumn{2}{|c|}{$\begin{array}{c}\text { Chuvas }>= \\
\quad 1 \mathrm{~mm}\end{array}$} & \multicolumn{2}{|c|}{ Amplitude } \\
\hline & Média & Desvio & Máxima & Minima & Média & Desvio & Máxima & Minima \\
\hline JAN & 311,7 & 137,8 & 836,8 & 134,9 & 15,8 & 1,9 & 21 & 13 \\
\hline FEV & 259,9 & 120.5 & 548,9 & 23,1 & 11,9 & 5,6 & 23 & 2 \\
\hline MAR & 261,2 & 131,2 & 667,1 & 93,4 & 13,3 & 3,3 & 20 & 7 \\
\hline $\mathrm{ABR}$ & 232.6 & 106,0 & 488,8 & 81,0 & 11,9 & 2.9 & 17 & 6 \\
\hline MAI & 146,6 & 92,3 & 426,5 & 18,4 & 8,0 & 3,6 & 16 & 4 \\
\hline JUN & 110.2 & 56,9 & 225,3 & 17,9 & 7,3 & 4,7 & 15 & 1 \\
\hline JUL & 98,6 & 46,7 & 183,0 & 20,4 & 7,1 & 2,6 & 14 & 1 \\
\hline AGO & 161.8 & 167,4 & 862,7 & 28,2 & 9,0 & 3,3 & 14 & 4 \\
\hline SET & 150,3 & 69,0 & 382,3 & 38,7 & 11,9 & 4,1 & 20 & 6 \\
\hline OUT & 209,9 & 80,0 & 412,1 & 65,4 & 14,2 & 3,3 & 19 & 10 \\
\hline NOV & 263,9 & 158,7 & 818,1 & 105,2 & 16,1 & 3,2 & 21 & 11 \\
\hline DEZ & 298,1 & 113,0 & 578,1 & 115,6 & 17,3 & 2,9 & 20 & 15 \\
\hline
\end{tabular}


Tabela 2. Médias mensais de umidade relativa, insolação e desvio-padrão (dp), registrados no período de 1970 a 1989 , para a região da Estação Biológica de Boracéia/SP. Posto metereológico E2 110 do CTH - DAEE.

UMIDADE RELATIVA

\begin{tabular}{|c|c|c|c|c|c|c|}
\hline Mês & Média & $\mathrm{dp}$ & Amplitude & Média & $\mathrm{dp}$ & Amplitude \\
\hline JAN & 86,27 & 2,99 & $99-59$ & 138,6 & 39.3 & $220-96$ \\
\hline FEV & 85.20 & 3,67 & $99-60$ & 155,5 & 47,7 & $249-88$ \\
\hline MAR & 87,13 & 3,25 & $99-65$ & 147,6 & 36.4 & $220-67$ \\
\hline ABR & 87,53 & 2,77 & $99-61$ & 146,8 & 27,1 & $198-98$ \\
\hline MAI & 85.60 & 3,29 & $99-63$ & 156.4 & 25,3 & $195-99$ \\
\hline UN & 84.47 & 3,70 & $99-49$ & 152,1 & 31,9 & $221-104$ \\
\hline Лん & 83.40 & 4.15 & $100-52$ & 177,9 & 25,3 & $231-145$ \\
\hline AGO & 84.20 & 3,47 & $100-53$ & 162,0 & 32,0 & $239-83$ \\
\hline SET & 86,60 & 4.53 & $100-59$ & 127,5 & 31.5 & $184-62$ \\
\hline OUT & 87.47 & 3.56 & $100-64$ & 125.4 & 23,0 & $71-90$ \\
\hline NOV & 87,27 & 3,35 & $100-60$ & 130.2 & 35,0 & $184-79$ \\
\hline DEZ & 87,00 & 3,21 & $99-67$ & 118,1 & 31,4 & $169-47$ \\
\hline ANO & 86.01 & 3,68 & $100-49$ & 144.8 & 17,4 & $249-47$ \\
\hline
\end{tabular}

INSOLAÇÃO 
Tabela 3. Médias das temperaturas médias, máximas e mínimas, e valores máximos e mínimos absolutos registrados para a Estação Biológica de Boracéia/SP. Posto metereológico E2 110 do CTH DAEE, período de 1970 a 1989.

TEMPER A T URAS

\begin{tabular}{|c|c|c|c|c|c|c|}
\hline \multirow[b]{2}{*}{ Mês } & \multicolumn{4}{|c|}{ Médias } & \multicolumn{2}{|c|}{ Absolutas } \\
\hline & Média & Desvio & Máxima & Mínima & Máxima & Mínima \\
\hline JAN & 20,95 & 1,36 & 23,1 & 18,4 & 33,8 & 6,6 \\
\hline FEV & 21,53 & 0,92 & 23,0 & 19,8 & 34,9 & 9,6 \\
\hline MAR & 20.55 & 0,98 & 22.6 & 19.0 & 33,3 & 2,2 \\
\hline$A \dot{B} R$ & 17,87 & 1,33 & 20,2 & 15,8 & 31,1 & 0,0 \\
\hline MAI & 16.41 & 1,44 & 19.2 & 14,1 & 28,8 & $-2,4$ \\
\hline JUN & 15,18 & 1,11 & 17,1 & 13,4 & 28,2 & $-2,6$ \\
\hline JUL & 14,76 & 1,53 & 17,5 & 12.4 & 29,0 & $-0,9$ \\
\hline AGO & 15,48 & 1,21 & 17,4 & 13,3 & 30.6 & 2,3 \\
\hline SET & 15,86 & 0,95 & 17,8 & 14,6 & 33,0 & 3,0 \\
\hline OUT & 17,39 & 1,32 & 19,6 & 15,3 & 34,0 & 4,0 \\
\hline NOV & 18.61 & 1,58 & 21.2 & 15,6 & 33,6 & 6,6 \\
\hline DEZ & 20,15 & 0,98 & 22,1 & 18,6 & 32,4 & 2,9 \\
\hline ANO & 17,89 & 2,62 & 23,1 & 12,4 & 34,9 & $-2,6$ \\
\hline
\end{tabular}




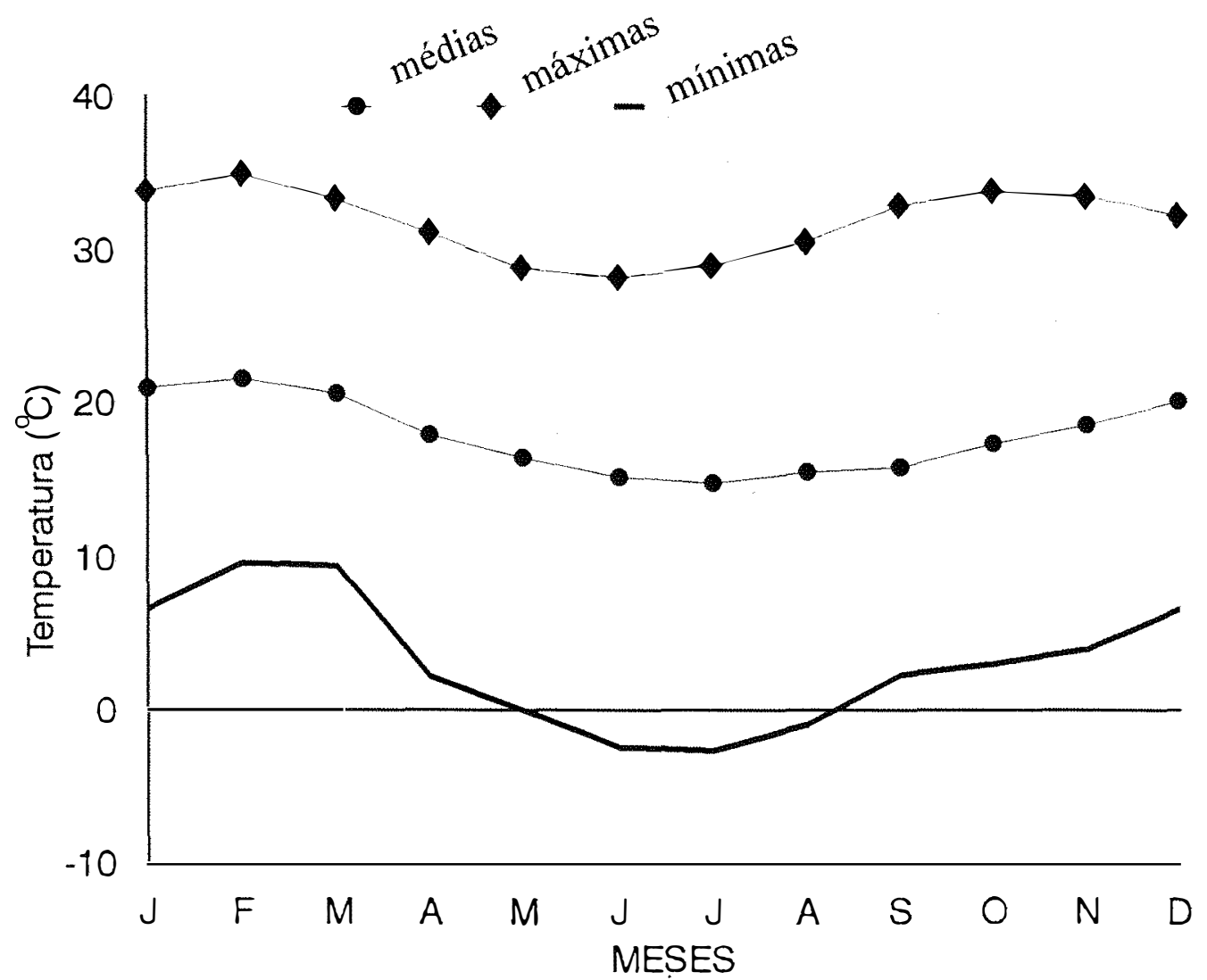

Figura 5. Variaçào das temperaturas médias, máximas e mínimas absolutas no período de 1970 a 1989, para a regiào da Estação Biológica de Boracéia/SP. 


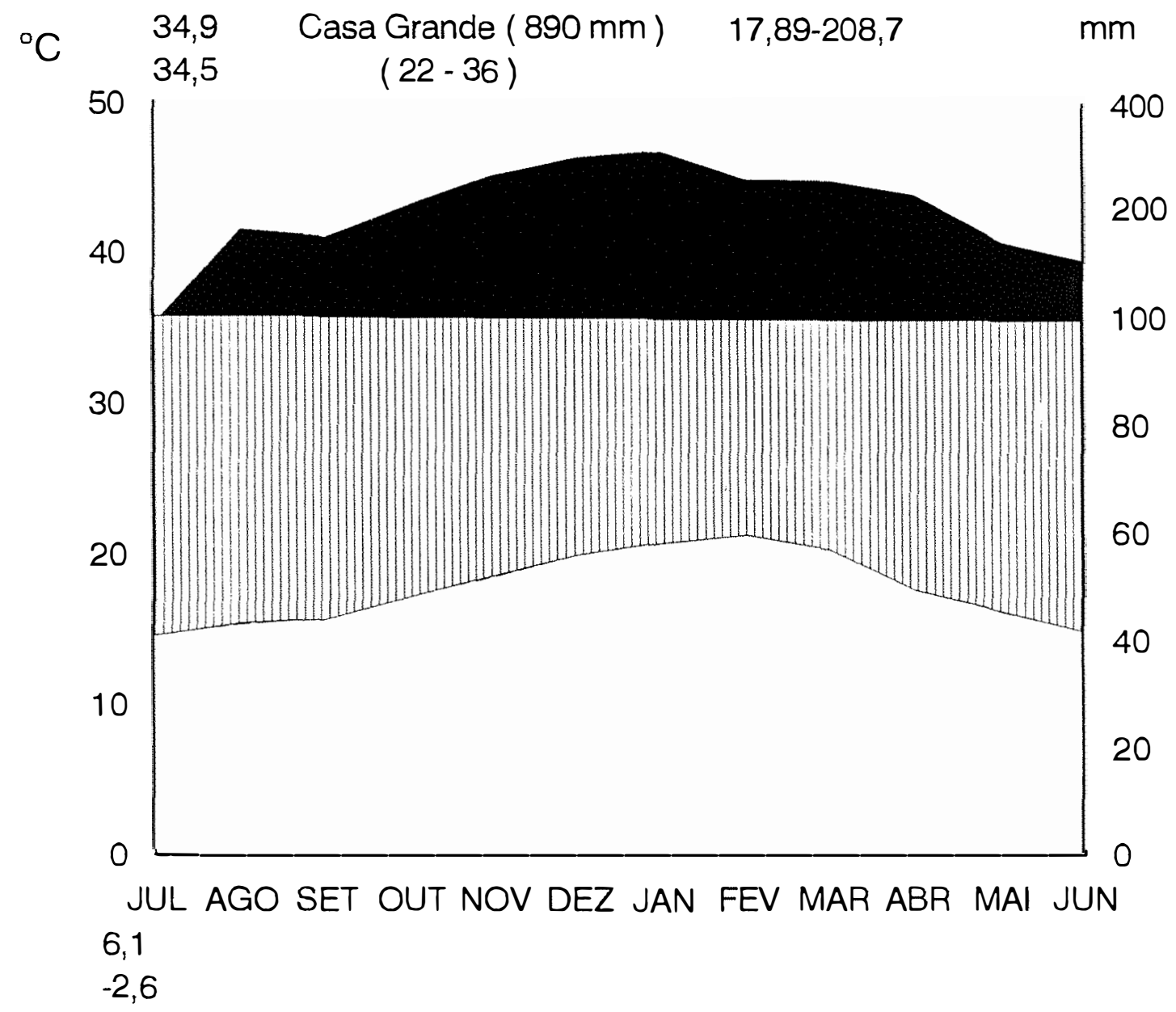

Figura 6. Climadiagrama para a região da Estação Biológica de Boracéia a área em negrito está reduzida em 1/10, e a área em hachuras, período chuvoso, de acordo com o método gráfico de WALTER (1984). 


\subsection{A SERAPILHEIRA}

\subsubsection{Trabalho de Campo}

A serapilheira, para a estimativa de deposição mensal e anual, foi amostrada através de coletores de madeira, com as dimensões de $1,0 \times 0,50 \mathrm{~m}$, e com o fundo de tela de nailon, com $1,0 \mathrm{~mm}^{2}$, de malha. Esses coletores foram distribuídos aleatoriamente, em uma área de 1 ha, sob o dossel da floresta.

Tabela 4. Análises químicas de amostras de solo, das profundidades 0-20, 20-40 e 40-60cm, para o local do experimento na Estação Biológica de Boracéia/SP.

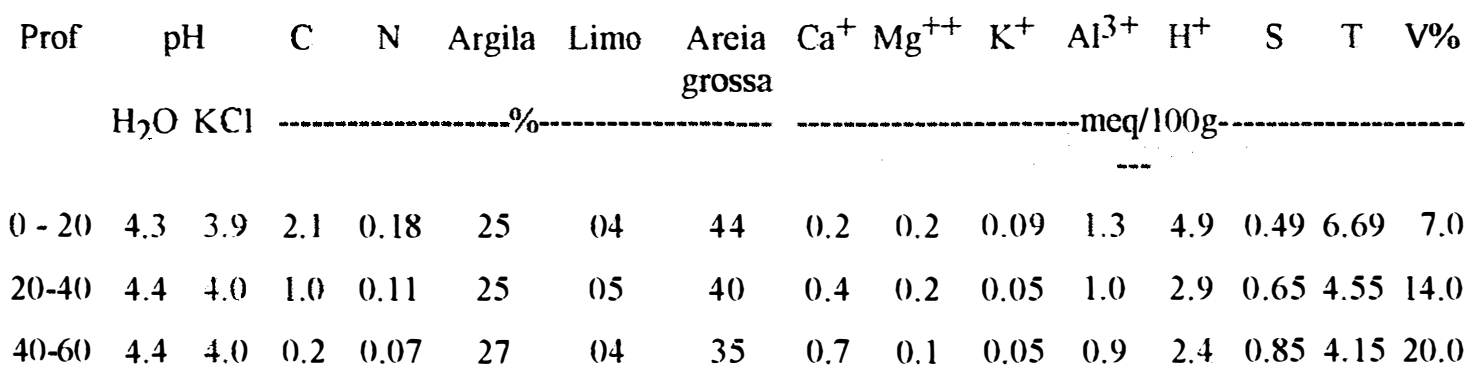


A coleta do material abrangeu um periodo de dois anos, entre março de 1985 e fevereiro de 1987, em intervalos mensais. O material era coletado, acondicionado em sacos de papel e enviado para a pré-secagem. realizada no laboratório da Estação Biológica de Boracéia e posterionnente para os procedimentos de laboratório.

\subsubsection{Métodos de Laboratório}

Nos laboratórios da Divisão de Dasonomia do Instituto Florestal, a serapilheira foi colocada em estufa de circulação forçada, a $70^{\circ} \mathrm{C}$, por dois dias. Procedeu então, a separação das frações folhas e ramos. Os componentes que não se enquadravam nessas duas categorias, eram englobados na categoria outros. Essas frações eram então colocadas, na estufa à temperatura de $80^{\circ} \mathrm{C}$, até registrarem peso constante e, posteriormente eram pesadas em balança com 0,01 gramas de precisão, para a obtenção do peso da biomassa seca. Os conteúdos dos coletores, por fração, eram reunidos em um único recipiente e moídos em moinho do tipo Willey. Aliquotas das frações foram enviadas para as análises químicas, no laboratório de Radioquímica do Centro de Energia Nuclear na Agricultura - CENA, da Escola Superior de Agricultura "Luiz de Queiroz", da Universidade de São Paulo. 


\subsubsection{Análises Químicas}

Seguindo as orientaçōes de ZAGATTO et al. (1981), e objetivando a análise quantitativa dos macronutrientes, procedeu-se o preparo das amostras para as análise.

Ao final, os valores das concentrações médias, em porcentagem, dos macronutrientes, eram multiplicados pelos pesos das respectivas quantidades de cada fração da serapilheira produzida mensalmente, obtendo-se assim o conteúdo de nutrientes depositado nesse período.

Os resultados de deposição de nutrientes, sobre a superfície do solo, através da queda da serapilheira, foram correlacionados com as condições climáticas.

\subsubsection{Serapilheira Acumulada e Decomposição}

$\mathrm{O}$ acúmulo de serapilheira foi estimado pela coleta de 10 amostras de serapilheira, em 4 períodos: maio, agosto, novembro e fevereiro, por meio de um quadrado de madeira de $1,0 \mathrm{~m}^{2}$ locado aleatoriamente.

A porcentagem de decomposição da serapilheira foi avaliada com a utilização de bolsas de tela de nailon (malha de $1,0 \mathrm{~mm}^{2}$ ) nas quais foram colocadas folhas que compunham a serapilheira, tomando-se o cuidado para que 
fossem recém-caídas.

Essas folhas foram previamente secas, para a retirada do excesso de umidade, misturadas, pesadas e colocadas nas bolsas. Essas bolsas, foram distribuídas sobre o solo em março de 1985, ao lado das bandejas de coleta de serapilheira.

A cada dois meses procedia-se à retirada de 10 bolsas, aleatoriamente. As folhas contidas em cada bolsa eram retiradas e, após a secagem eram pesadas, moídas e analisadas quimicamente, segundo a metodologia de ZAGATTO et al. (1981).

A taxa de decomposição instantânea da serapilheira foi obtida pela equação de OLSON (1963).

$$
\mathrm{K}=\mathrm{L} / \mathrm{Xss}
$$

onde

$\mathrm{L}$ = quantidade de serapilheira produzida por ano em kg.ha-1

$$
\text { Xss = média das quatro amostras da serapilheira }
$$
acumulada em kg.ha-1

O tempo necessário para o desaparecimento de $50 \%$ da serapilheira foi obtido pela equação $\mathrm{T}_{50}=-\ln 0,5 / \mathrm{K}$ e de $95 \%$, $\mathrm{T}_{95}=-\ln 3 / \mathrm{K}$, segundo SHANKS \& OLSON ( 1961). O tempo médio necessário para a renovação foi estabelecido pela formula 1/K segundo OLSON (1963) e HOPKIN (1966).

Para a análise estatistica utilizou-se o coefeciente de correlação de Pearson, do Sistema de análise estatística (SAS). 


\section{RESULTADOS E DISCUSSÃO}

\subsection{CLIMA}

$\mathrm{Na}$ tabela 5 são apresentados os valores médios de pluviosidade, temperatura, umidade relativa e insolação, obtidos para a região de Boracéia, durante os dois anos de experimento, isto é, de 1985 a 1987 (posto E2 110, Casa Grande, do C.T.H. - DAEE).

A pluviosidade média anual, para o período estudado, foi de $2.451,35 \mathrm{~mm}$, valor próximo a $2.504,8 \mathrm{~mm}$, registrado no período de 1953 a 1989 . A variação mensal da pluviosidade mostrou-se similar à observada para 0 intervalo de 1953 a 1989, com pequenas discrepâncias mensais (figura 7).

A temperatura média anual de $17,7^{\circ} \mathrm{C}$, foi semelhante à média registrada para o período de 1970 a 1989 . Na figura 8. tem-se a representação gráfica desses dados e das oscilações sazonais, entre os diferentes períodos. 
Tabela 5.

Valores mensais médios de temperatura, insolação e umidade relativa e total anual médio da pluviosidade, para os dois anos do estudo (Posto E2 - 110 - Casa Grande, CTH - DAEE).

\begin{tabular}{|c|c|c|c|c|}
\hline MÊS & $\begin{array}{c}\text { TEMPERATURA } \\
{ }^{\circ} \mathrm{C}\end{array}$ & $\underset{m m}{\text { PLUVIOS IDADE }}$ & $\begin{array}{r}\text { INSOLAÇÃO } \\
\text { horas }\end{array}$ & $\begin{array}{r}\text { UMIDADE } \\
\frac{\circ}{0}\end{array}$ \\
\hline MAR/ 85 & 20,5 & 294,0 & 108,5 & 91 \\
\hline $\mathrm{ABR} / 85$ & 21,0 & 400,3 & 174,6 & 90 \\
\hline MAI / 85 & 15,8 & 213,1 & 134,9 & 92 \\
\hline JUN / 85 & 14,0 & 152,3 & 171,1 & 89 \\
\hline JUL/8 5 & 13,8 & 47,1 & 206,3 & 86 \\
\hline $\mathrm{AGO} / 85$ & 13,4 & 93,5 & 239,5 & 85 \\
\hline SET/85 & 15,2 & 135,3 & 161,2 & 88 \\
\hline OUT / 85 & 15,9 & 48,9 & 123,7 & 90 \\
\hline NOV / 85 & 17,6 & 99,1 & 184,6 & 87 \\
\hline DEZ/8 5 & 18,3 & 142,8 & 143,4 & 89 \\
\hline JAN / 86 & 19,8 & 152,2 & 156,6 & 88 \\
\hline $\mathrm{FEV} / 86$ & 21,2 & 169,2 & 168,4 & 87 \\
\hline Média & 17,2 & - & 164,4 & 88 \\
\hline Total & - & 1947,8 & - & . \\
\hline MAR/ 86 & 21,3 & 343,0 & 123,2 & 90 \\
\hline $\mathrm{ABR} / 86$ & 20,8 & 531,3 & 198,9 & 89 \\
\hline MAI / 86 & 17,7 & 198,5 & 134,1 & 89 \\
\hline JUN / 86 & 16,5 & 67,9 & 194,1 & 87 \\
\hline JUL / 86 & 14,1 & 200,1 & 168,6 & 86 \\
\hline $\mathrm{AGO} / 86$ & 15,0 & 134,5 & 184,2 & 87 \\
\hline SET/ 86 & 15,2 & 68,0 & 157,8 & 88 \\
\hline OUT / 86 & 17,2 & 170,6 & 123,2 & 89 \\
\hline NOV / 86 & 17,9 & 304,0 & 174,1 & 86 \\
\hline $\mathrm{DEZ} / 86$ & 21,2 & 248,4 & 114,9 & 87 \\
\hline $\mathrm{JAN} / 87$ & 21,3 & 197,5 & 137,7 & 88 \\
\hline $\mathrm{EEV} / 87$ & 20,7 & 491,1 & 88,5 & 89 \\
\hline Média & 17,7 & - & 157,2 & 88 \\
\hline Total & - & 2954,9 & & \\
\hline
\end{tabular}




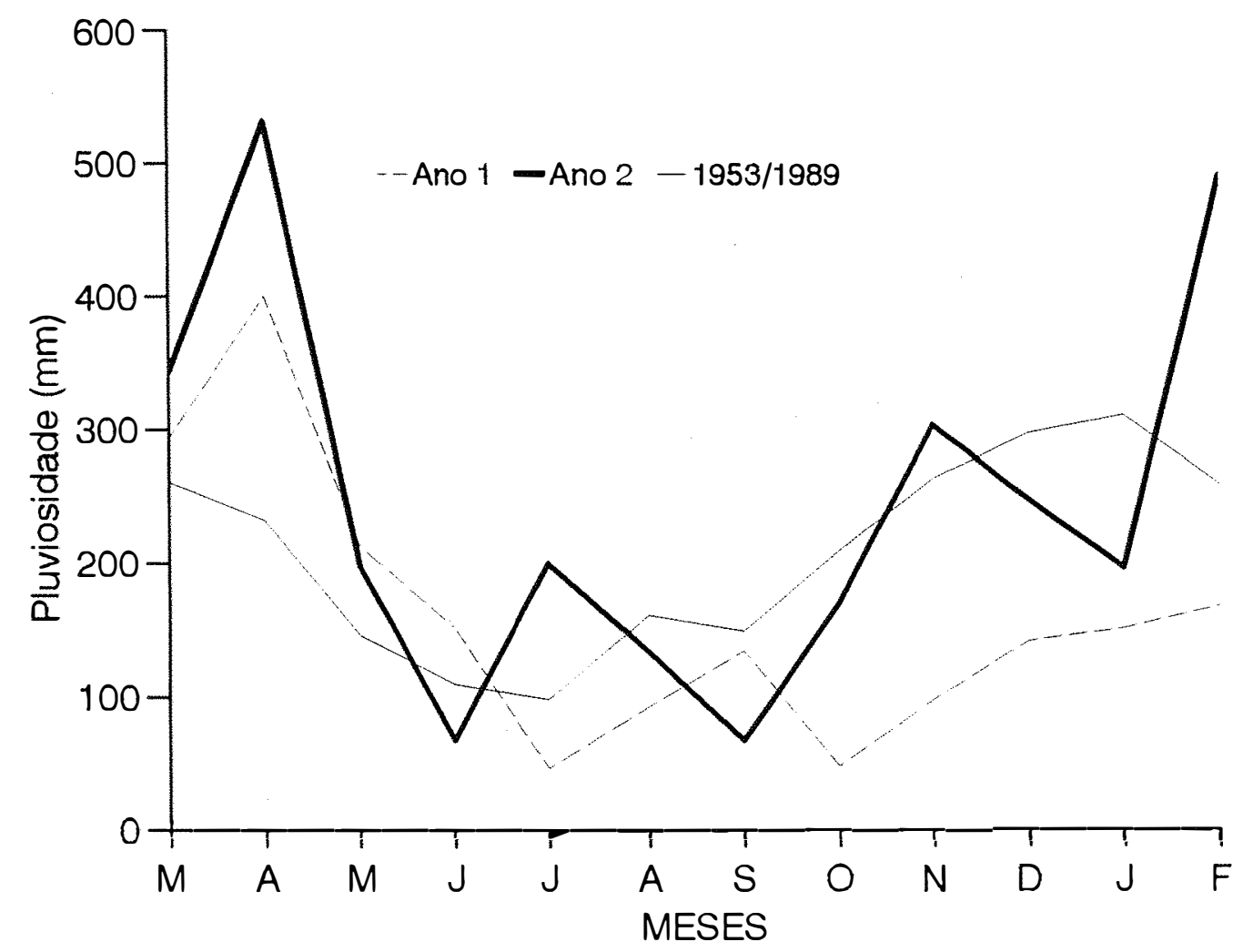

Figura 7. Valores mensais de pluviosidade, durante o período do experimento, para a região da Estação Biológica de Boracéia/SP. 


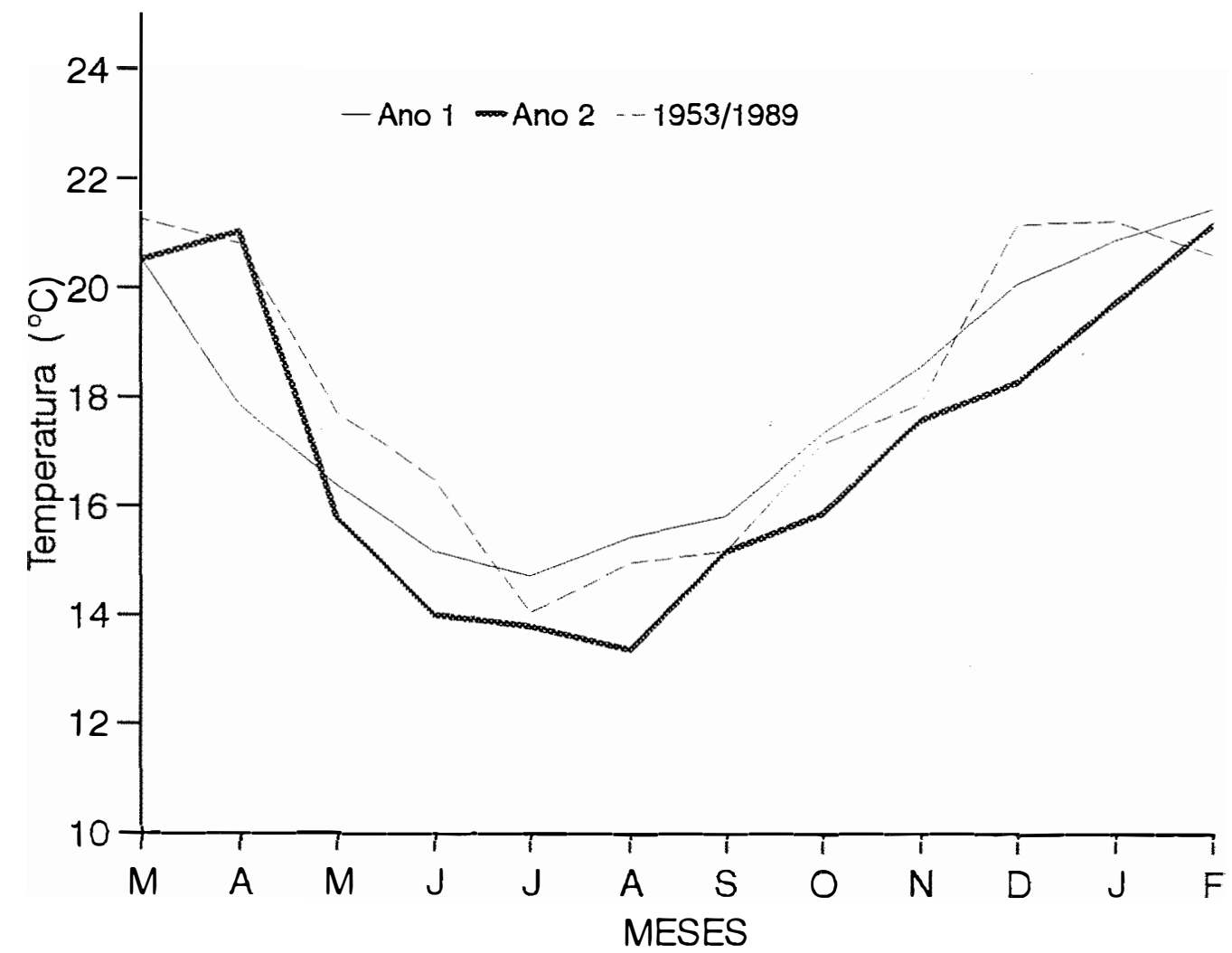

Figura 8. Valores mensais das temperaturas médias, durante o período do experimento, para a região da Estação Biológica de Boracéia/SP. 
A umidade relativa média anual mostrou-se semelhante à observada para o intervalo entre 1970 a 1989 (figura 9). Os valores não foram inferiores a 86\%, nos 24 meses de observação, não ocorrendo nítida oscilação sazonal.

Os valores de insolação para o período, foram superiores $(12,4$ horas) aos valores médios observados entre 1970 a 1989 (figura 10).

A pluviosidade, temperatura, umidade relativa e insolação, para o período do experimento, em relação ao período entre 1953 a 1989, não apresentaram diferenças significativas para região da Estação Biológica de Boracéia (Posto meteorológico de Casa Grande), denotando a não ocorrência de deficit hídrico, confirmando os resultados visíveis no climadiagrama (figura 6).

\subsection{DEPOSIÇÃO DE SERAPILHEIRA}

Como mostra a tabela 6 , a deposição anual de serapilheira foi de 5.702,24 e 6.405,95 kg.ha-1, respectivamente, para o primeiro e o segundo ano. Esses valores situam-se abaixo dos observados em florestas brasileiras (tabela 7), e dos previstos por BRAY \& GORHAM (1964) e LONSDALE (1988), para florestas localizadas aproximadamente na mesma latitude da Estação Biológica de Boracéia. 


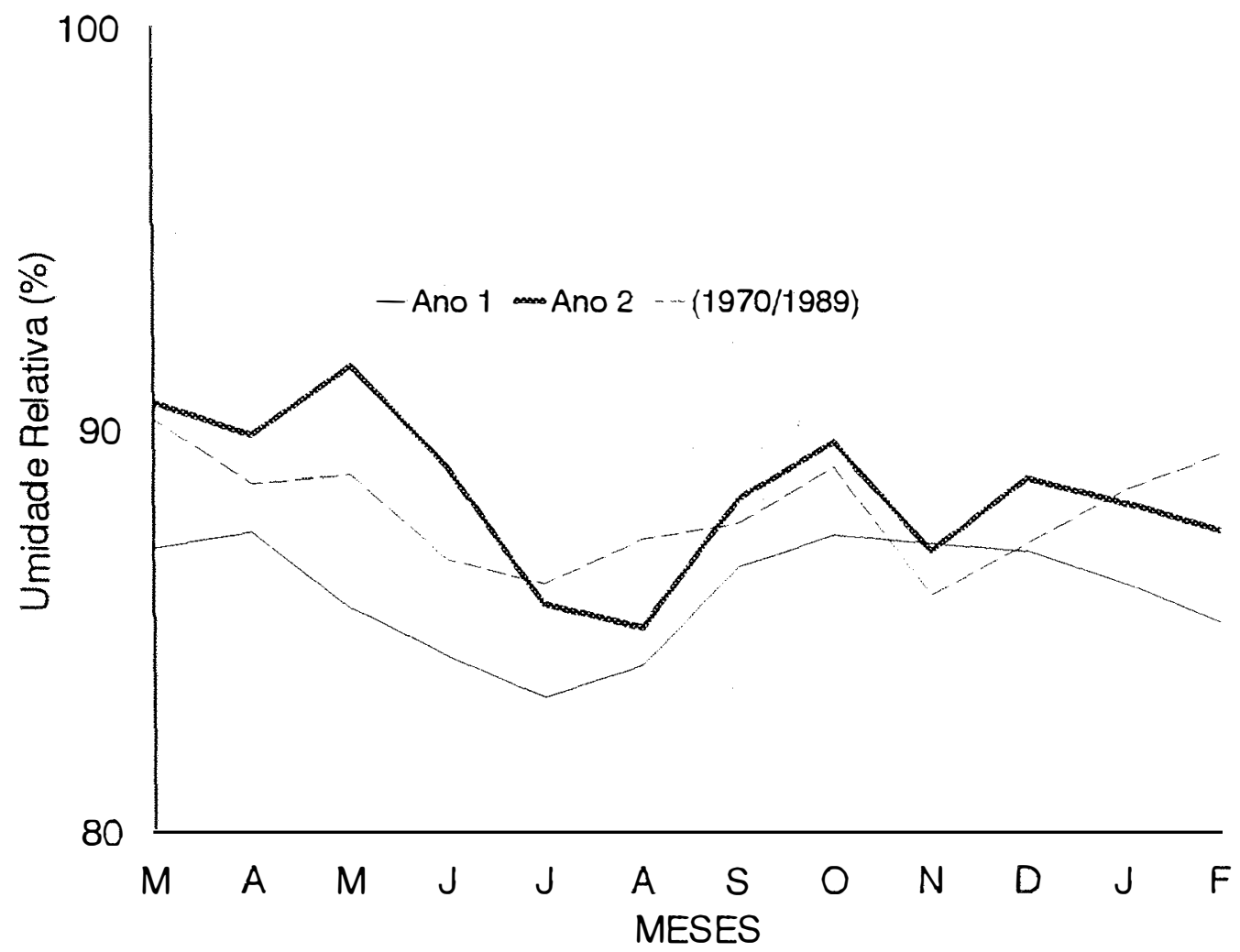

Figura 9. Valores de umidade relativa, observados durante o período do experimento, para a região da Estação Biológica de Boracéia/SP. 


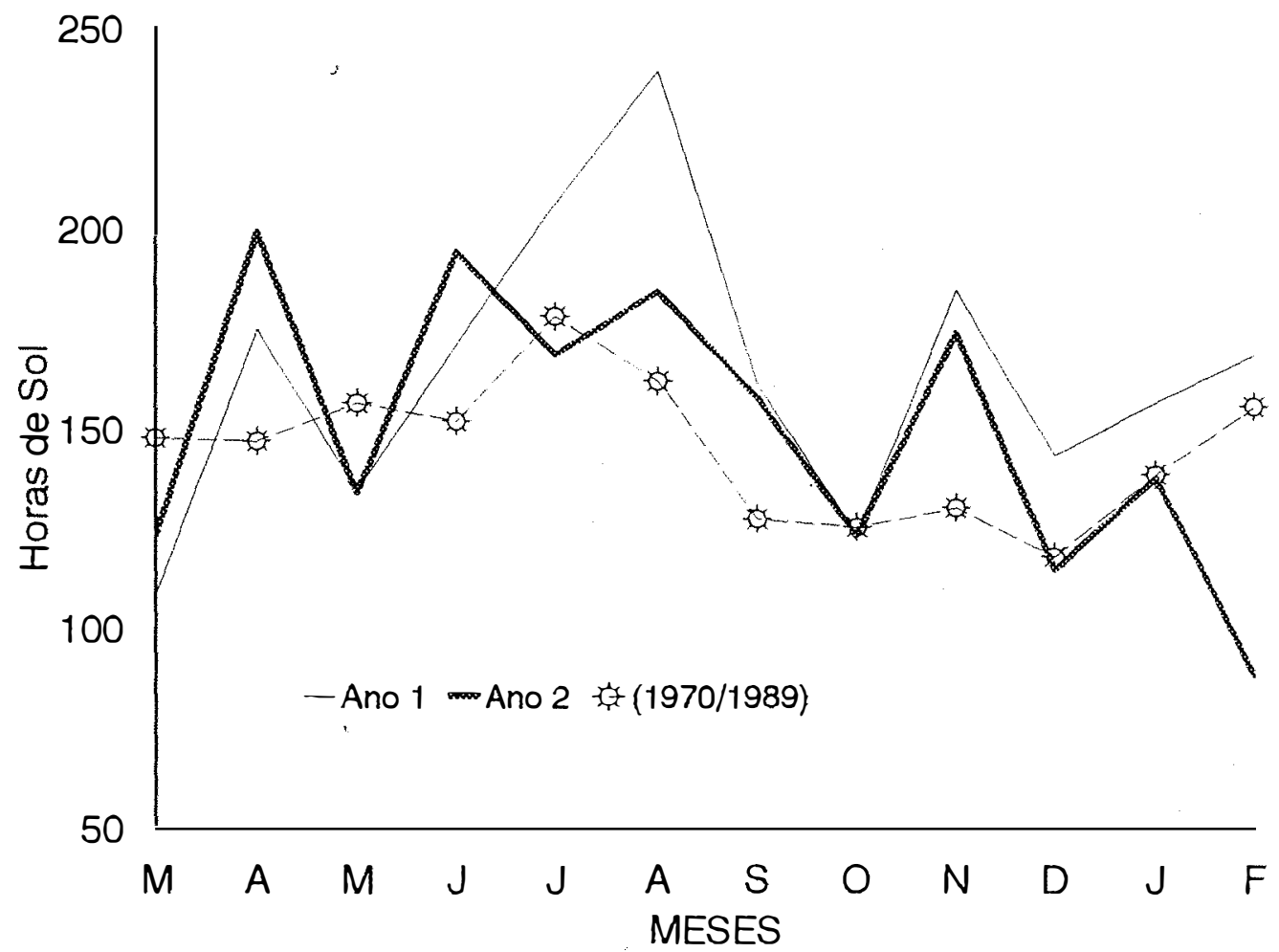

Figura 10. Horas de sol, durante o período do experimento, para a região da Estação Biológica de Boracéia/SP. 
Nos estudos realizados por CUSTODIO FILHO et al. ${ }^{* *}$ em Cunha (Parque Estadual da Serra do Mar) e por VARJABEDIAN \& PAGANO (1988) na Ilha de Santo Amaro, Guarujá, ambos no estado de São Paulo, e por JACKSON (1978) na Reserva Biológica de Nova Lombardia/ES., foram observados valores mais altos de deposição de serapilheira. Todavia, a deposição foi superior aos valores obtidos por DOMINGOS et al. (1990), em estudos realizados na Reserva de Paranapiacaba, em Santo André/SP, e por LEITÃO FILHO et al. (1993), em áreas do Parque Estadual da Serra do Mar, em Cubatão/SP, locais estes acentuadamente afetados pela poluição proveniente do complexo industrial de Cubatão.

Uma maior deposição de serapilheira, foi também observada em florestas mesófilas perenifólias, no município de São Paulo, por MEGURO et al. (1979), TEIXEIRA et al. (1992) e por MORELLATO-FONZAR (1987) em uma floresta de altitude, próximo à cidade de Jundiaí/SP.

*** CUSTODIO FILHO,A: ALMEIDA,M.C.P. \& DIAS.A.C. Produção de serapilheira em um trecho de Mata Atlântica, Núcleo Cunha, P.E. Serra do Mar. Revista do Institata, Florestal. São Paulo. 
Tabela 6. Deposição mensal da serapilheira, durante dois anos (1985/1987), Estação Biológica de Boracéia/SP.

\begin{tabular}{|c|c|c|}
\hline Lo ano & $\mathrm{kg} \cdot \mathrm{ha}^{-1}$ & Desvio Padrão \\
\hline MARÇO & 450,91 & 134,82 \\
\hline ABRIL & 617,45 & 146,87 \\
\hline MAIO & 208,65 & 42,41 \\
\hline JUNHO & 381,21 & 108,70 \\
\hline JULHO & 490,20 & 168,82 \\
\hline AGOSTO & 582,05 & 170,65 \\
\hline SETEMBRO & 388,56 & 63,99 \\
\hline OUTUBRO & 309,27 & 52,73 \\
\hline NOVEMBRO & 407,72 & 126,59 \\
\hline DEZEMBRO & 676,24 & 171,88 \\
\hline JANEIRO & 651,10 & 205,60 \\
\hline FEVEREIRO & 538,88 & 100,63 \\
\hline Total & 5702,24 & - \\
\hline 20 ano & $\mathrm{kg} \cdot \mathrm{ha}^{-1}$ & Desvio Padrão \\
\hline MARÇO & 535,77 & 151,22 \\
\hline ABRIL & 711,85 & 104,81 \\
\hline MAIO & 309,67 & 80,67 \\
\hline JUNHO & 378,29 & 63,62 \\
\hline JULHO & 264,76 & 57,65 \\
\hline AGOSTO & 372,65 & 65,56 \\
\hline SETEMBRO & 410,74 & 69,91 \\
\hline OUTUBRO & 805,93 & 139,24 \\
\hline NOVEMBRO & 1024,07 & 194,27 \\
\hline DEZEMBRO & 612,66 & 119,54 \\
\hline JANEIRO & 483,80 & 59,25 \\
\hline FEVEREIRO & 495,76 & 72,19 \\
\hline Total & 6405,95 & - \\
\hline
\end{tabular}




\section{Tabela 7. Valores da serapilheira produzida em florestas tropicais brasileiras.}

\begin{tabular}{|c|c|c|c|}
\hline Vegetação & $\begin{array}{l}\text { Serapilheira } \\
(\mathrm{kg} / \mathrm{ha} / \mathrm{ano})\end{array}$ & $\begin{array}{c}\begin{array}{c}\text { Folhedo } \\
(\mathrm{kg} / \mathrm{ha} / \mathrm{ano})\end{array} \\
\end{array}$ & Autores \\
\hline Floresta Pluvial Atlântica (Espirito Santo) & - & 4620 & JACKSON (1978) \\
\hline Floresta Pluvial Atlântica (São Paulo) & 7925 & 5039 & $\begin{array}{l}\text { VARIABEDIAN \& } \\
\text { PAGANO (1988) }\end{array}$ \\
\hline Floresta Pluvial Atlântica (São Paulo) & 3810 & - & $\begin{array}{l}\text { DOMINGOS et al. } \\
(1990)\end{array}$ \\
\hline Floresta Pluvial Atlântica (São Paulo) & 4460 & 3638 & $\begin{array}{l}\text { LEITÃO FILHO et al. } \\
\text { (1993) }\end{array}$ \\
\hline Floresta Mesótila (São Paulo) & 9410 & 5890) & MEGURO et al. (1979a) \\
\hline Floresta Residual (São Paulo) & 7288 & 4906 & TEIXEIRA et al. (1992) \\
\hline Floresta Mesófila Semidecidua (São Paulo) & 8643 & 5361 & PAGANO (1985) \\
\hline Floresta Mesófila Semidecidua (São Pauloi & 11590 & 7680 & DINIZ (1987) \\
\hline Floresta Mesófila Semidecidua (São Paulo) & 8800 & 5680 & CESAR (1988) \\
\hline Floresta Mesótila Semidecidua (São Paulo) & 6568 & 4737 & SCHLITILER (1990) \\
\hline Floresta Mesófila Semidecidua (São Paulo) & 8600 & 5500 & $\begin{array}{l}\text { MORELLATO-FONZAR } \\
\text { (1992) }\end{array}$ \\
\hline Floresta Mesófila de Altitude (São Paulo) & $7(1000$ & 4900 & $\begin{array}{l}\text { MOELLATO-FONZAR } \\
\text { (1992) }\end{array}$ \\
\hline Floresta Mesófila Semidecidua (São Paulo) & - & 8505 & $\begin{array}{l}\text { POGGIANI \& } \\
\text { MONTEIRO IÜJNIOR } \\
\text { (1990) }\end{array}$ \\
\hline Floresta Tropical (Amazônia) & 7300 & - & SILVA \& LOBO (1982) \\
\hline Floresta Tropical (Amazônia) & 6656 & 4757 & SLVA (1984) \\
\hline Floresta Pluvial Atlântica (São Paulo) & 6054 & 4403 & Esse estudo \\
\hline
\end{tabular}

Para as florestas mesófilas semidecíduas, características do interior do Estado de São Paulo. das regiões do domínio da depressão periférica e do planalto ocidental, as produções anuais de serapilheira. também foram maiores que no presente estudo. DINIZ (1987) em Araras, estimou uma deposição de 
11.500 kg.ha-1; DELITTI (1984) em Mogi - Guaçu, obteve 6.687 kg.ha-1; PAGANO (1985) em Rio Claro, 8.643 kg.ha-1; CESAR (1988) em Anhembi, $8.800 \mathrm{~kg} \cdot \mathrm{ha}^{-1}$; SCHLITTLER (1990) em Teodoro Sampaio, $8.600 \mathrm{~kg} \cdot \mathrm{ha}^{-1} \mathrm{e}$ POGGIANI \& MONTEIRO JÚNIOR (1990) em Piracicaba relatam 8.500 kg.ha-1 de folhedo.

SILVA \& LOBO (1982) e SILVA (1984) em floresta de terra firme da Amazônia, bem como em outros locais, evidenciam resultados sempre maiores de deposição de serapilheira (tabela 7).

A média dos valores mensais de deposição de serapilheira são apresentados na tabela 8 e na figura 11. Observa-se uma maior deposição de serapilheira no mês de novembro e menor deposição em maio. A análise desses dados indica a ocorrência de uma tendência de maior deposição de serapilheira na primavera e verão (novembro/dezembro) e no início do outono (abril). Todavia, nota-se que além dessas variações, ocorreram também pequenos picos de deposição nos meses de junho e agosto, que podem estar associados ao aumento expressivo no volume de chuvas e das tempestades fortes, que são relativamente freqüentes nessa região. Não foi observada. todavia, uma correlação estatisticamente significativa, entre as condições climáticas e a deposição de serapilheira. Considerando-se as quatro estações do ano, as deposições em ordem decrescente foram observadas na primavera, verão, outono e inverno.

Os valores mensais de deposição de serapilheira, como também das frações: folhas, ramos e, observados durante os dois anos de pesquisa, estão representados na tabela 9. As comparações entre esses dados. a pluviosidade, a temperatura, a umidade relativa e a insolação, são apresentadas 
nas figuras 12 e 13 Observa-se que os meses mais quentes e chuvosos favoreceram a deposição de serapilheira, porem, mesmo nos meses frios podem ocorrer picos menores de deposição principalmente em relação à fração folhas.

Pode-se dizer portanto, que há relações perceptíveis mas não estatisticamente comproveis entre as condições climáticas e a deposição de serapilheira ou suas frações, tanto para os valores máximos, como para os valores mínimos.

Há de se observar (figuras 12 e 13), todavia, uma tendência de aumento na deposição de serapilheira, associada ao aumento dos índices pluviométricos. resultado de um provável efeito fisico da água sobre à vegetação.

Esses dados corroboram a ausência de correlação entre a pluviosidade e a deposição de serapilheira, bem como a não ocorrência de sazonalidade marcante nessa vegetação.

A fração folhas contribui, em média. com $72,73 \%$ da serapilheira produzida anualmente, estando pouco acima dos padrões previstos por BRAY \& GORHAM (1964) que é de $62,4 \%$ e dos valores obtidos em trabalhos desenvolvidos em florestas brasileiras. VARJABEDIAN \& PAGANO (1988), em uma vegetaçào similar à do presente estudo, obtiveram $63,6 \%$. 
Tabela 8. Valores médios, em kg.ha-1, de deposição por fração e total de serapilheira para a região da Estação Biológica de Boracéia/SP.

$\begin{array}{crrrr}\text { Mês } & \text { Folha } & \text { Ramos } & \text { Outros } & \text { Total } \\ & & & & \\ \text { MAR } & 380,73 & 66,24 & 46,38 & 493,34 \\ \text { ABR } & 400,05 & 211,54 & 53,05 & 664,65 \\ \text { MAI } & 187,40 & 43,83 & 27,93 & 259,16 \\ \text { JUN } & 253,30 & 91,82 & 34,63 & 379,75 \\ \text { JUL } & 286,97 & 45,45 & 45,06 & 377,48 \\ \text { AGO } & 358,20 & 72,58 & 46,57 & 477,35 \\ \text { SET } & 271,64 & 76,62 & 51,39 & 399,65 \\ \text { OUT } & 432,95 & 73,40 & 51,25 & 557,60 \\ \text { NOV } & 539,16 & 81,84 & 94,89 & 715,90 \\ \text { DEZ } & 532,91 & 46,59 & 64,95 & 644,45 \\ \text { JAN } & 414,93 & 64,90 & 87,62 & 567,45 \\ \text { EEV } & 345,08 & 99,30 & 72,95 & 517,32 \\ \text { Total } & 4403,31 & 974,13 & 676,66 & 6054,10\end{array}$




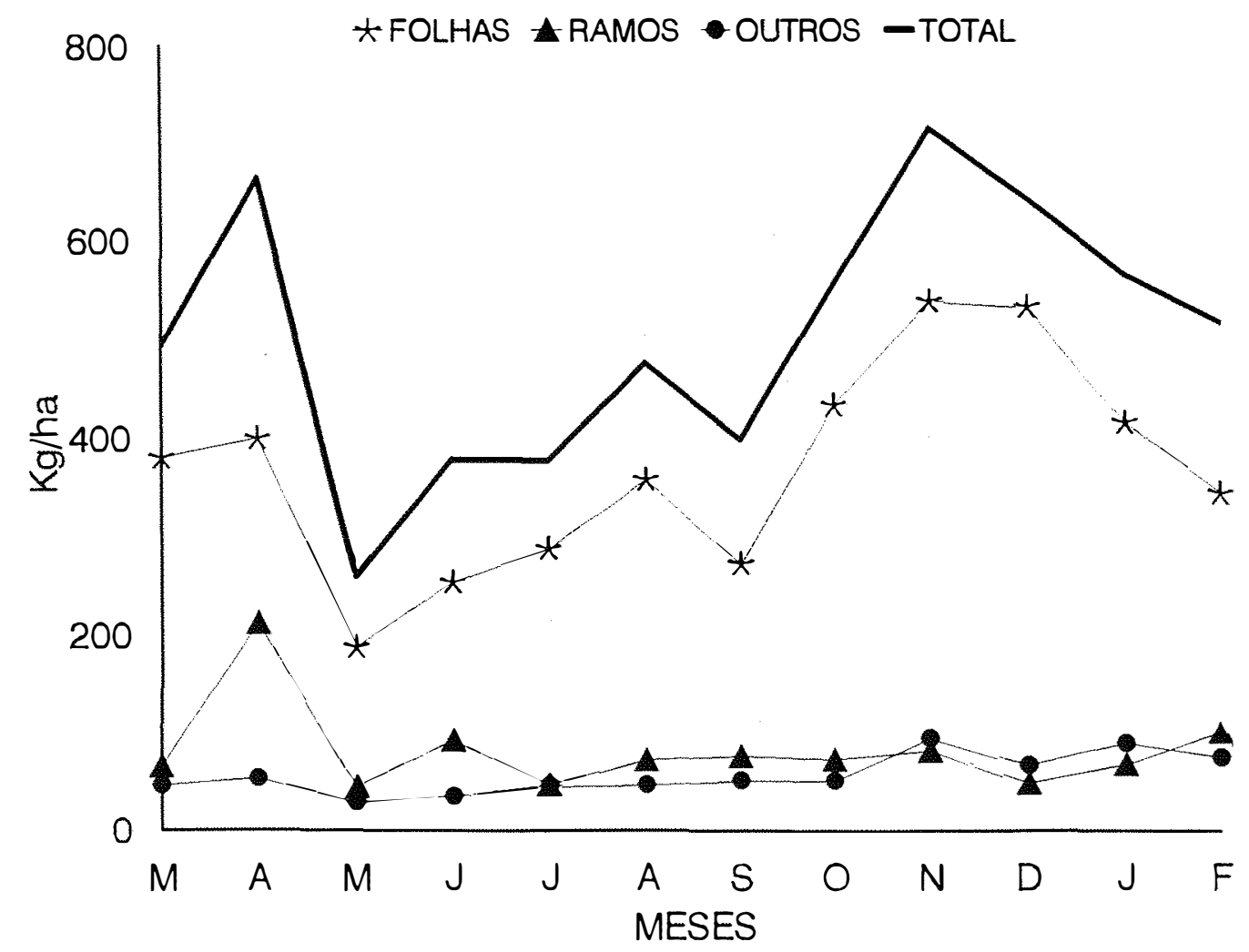

Figura 11. Valores médios de folhas, ramos e da serapilheira produzida pela vegetação. na Estaçào Biológica de Boracéia/SP. 
Tabela 9. Deposiçào das diferentes frações de serapilheira, em kg.ha-1, ao longo de dois anos de observações (1985/1987), para a regiào da Estaçào Biológica de Boracéia/SP.

\begin{tabular}{|c|c|c|c|c|}
\hline MÊS & EOLHA & RAMOS & OUTROS & TOTAL \\
\hline MARCO & 329,17 & 71,13 & 50,61 & 450,91 \\
\hline ABRIL & 450,56 & 105,18 & 61,70 & 617,45 \\
\hline MAIO & 124,00 & 49,43 & 35,22 & 208,65 \\
\hline JUNHO & 253,12 & 97,30 & 30,79 & 81,21 \\
\hline JULHO & 392,82 & 53,48 & 43,90 & 490,20 \\
\hline AGOSTO & 416,34 & 101,63 & 64,09 & 582,05 \\
\hline SETEMBRO & 288,55 & 46,71 & 53,31 & 388,56 \\
\hline OUTUBRO & 218,85 & 35,23 & 55,20 & 309,27 \\
\hline NOVEMBRO & 328,72 & 26,15 & 52,85 & 407,72 \\
\hline DEZEMBRO & 561,76 & 54,83 & 59,65 & 676,24 \\
\hline JANEIRO & 469,09 & 80,61 & 101,40 & 651,10 \\
\hline EEVEREIRO & 391,15 & 86,57 & 61,16 & 538,88 \\
\hline TOTAL & 4224,12 & 808,25 & 669,87 & 5702,24 \\
\hline MARCO & 432,28 & 61,35 & 42,15 & 535,77 \\
\hline ABRIL & 349,55 & 317,90 & 44,40 & 711,85 \\
\hline MAIO & 250,79 & 38,24 & 20,65 & 309,67 \\
\hline JUNHO & 253,48 & 86,35 & 38,46 & 378,29 \\
\hline JULHO & 181,12 & 37,42 & 46,23 & 264,76 \\
\hline AGOSTO & 300,05 & 43,54 & 29,05 & 372,65 \\
\hline SETEMBRO & 254,74 & 106,54 & 49,46 & 410,74 \\
\hline OUTUBRO & 647,05 & 111,58 & 47,29 & 805,93 \\
\hline NOVEMBRO & 749,61 & 137,53 & 136,94 & 1024,07 \\
\hline DEZEMBRO & 504,05 & 38,35 & 70,25 & 612,66 \\
\hline JANEIRO & 360,76 & 49,20 & 73,84 & 483,80 \\
\hline FEVEREIRO & 299,01 & 112,03 & 84,73 & 495,76 \\
\hline TOTAL & 4582,50 & 1140,01 & 683,45 & 6405,95 \\
\hline MÉDIA & 4403,31 & 974,13 & 676,66 & 6054,10 \\
\hline
\end{tabular}



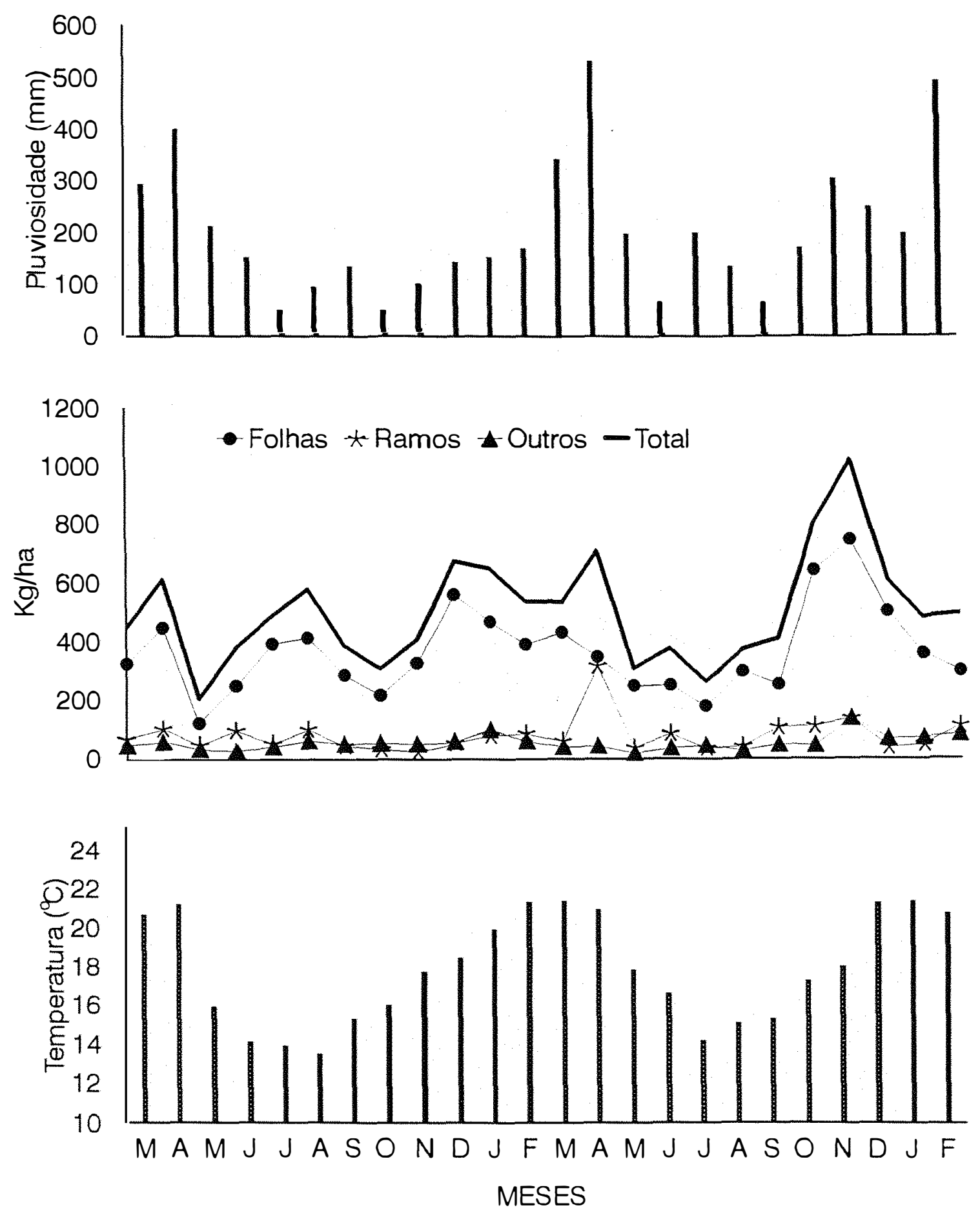

Figura 12. Serapilheira e frações produzidas em dois anos. na Estação Biológica de Boracéia/SP.. em relaçào à pluviosidade e temperatura. 

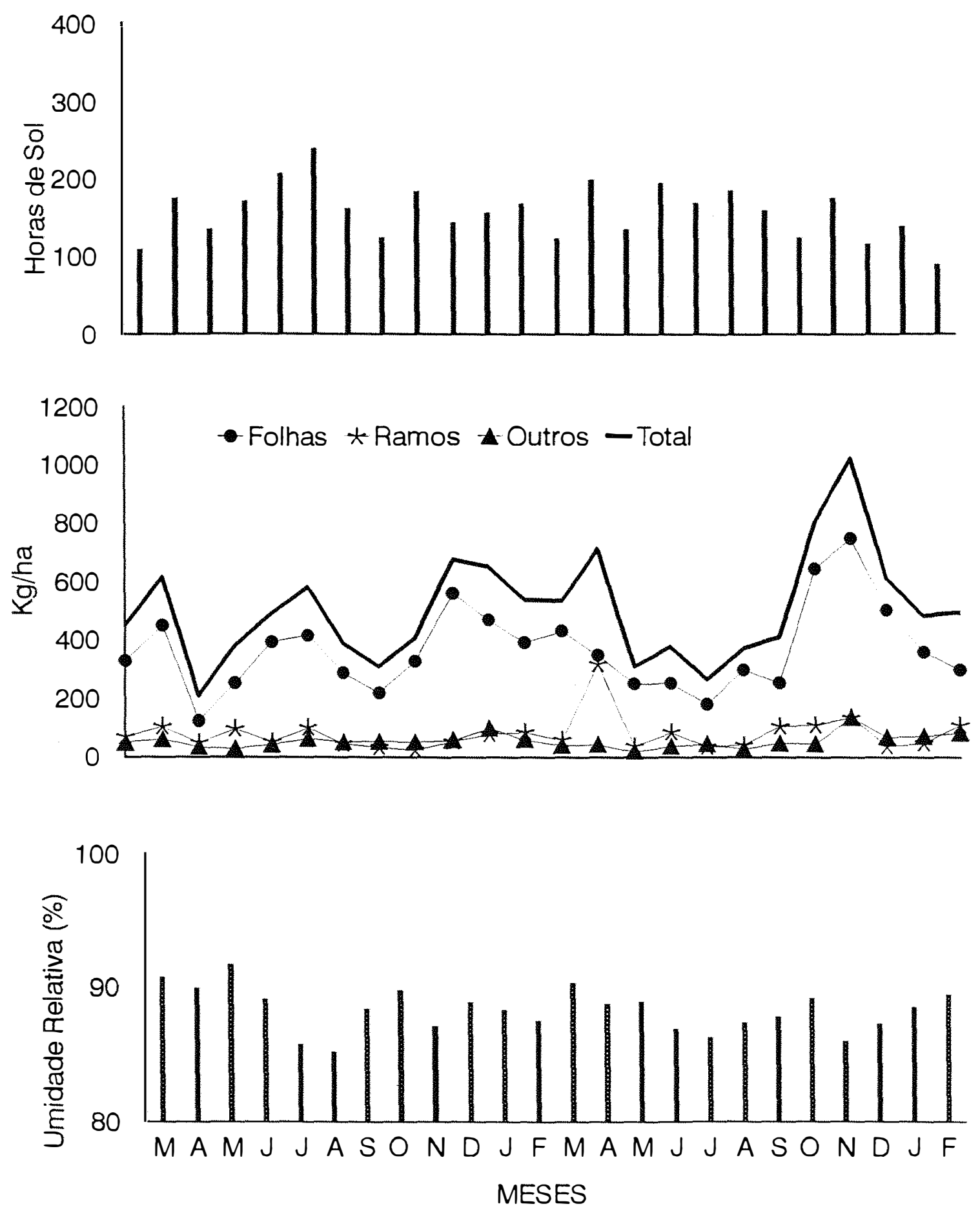

Figura 13. Serapilheira e fraçòes produzidas. em dois anos, na Estação Biológica de Boracéia/SP.. em relaçào a umidade relativa e insolaçâo. 
As frações ramos e outros contribuíram, respectivamente, com $16,09 \%$ e $11,29 \%$ da formação da serapilheira. O aumento na deposição da fração ramos, principalmente em abril do segundo ano pode estar associada às fortes tempestades.

A queda de inflorescências de Euterpe edulis é um dos fatores que afetou a variação da fração outros, sendo o mesmo comportamento observado por DOMINGOS et al. (1990).

Deve ser assinalado, portanto, que a deposição de serapilheira, ou de suas frações, não apresenta correlações estatisticamente significativas ao nível de 5\% com os fatores climáticos: pluviosidade, temperatura, umidade relativa e insolação.

Tudo indica que a floresta atlântica no estado de São Paulo não está sujeita a fatores de estresse relevantes. e que também não possui um período de caducifolia bem definido, sendo esse caráter variável para as diferentes espécies vegetais.

Esse padrão de deposição de serapilheira, sem variações significativas ao longo do ano, corresponde ao padrão observado nos trabalhos realizados na floresta pluvial atlântica no estado de São Paulo. Difere todavia, do comportamento observado em ouras formações florestais paulistas do interior, onde há sazonalidade na deposição de serapilheira, principalmente na estação seca (MEGURO et al., 1979; CARPANEZI, 1980; GARRIDO, 1981; PAGANO, 1985; DINIZ, 1987; MORELLATO-FONZAR, 1987; CESAR, 1988; 
POGGIANI \& MONTEIRO JÚNIOR, 1990; SCHLITTLER, 1990 ; TEIXEIRA et al., 1992).

Concordando com DELITTI (1984), a abscisão de folhas pode ser uma estratégia de minimização dos efeitos da perda de água pela transpiração durante as épocas de déficit hídrico. Essa afirmação é também, proposta por ALVIN (1964), que atribuiu a ocorrência de caducifolia ao déficit hídrico, provocando portanto uma sazonalidade marcante na derrubada de folhas nas florestas do interior do estado.

Ainda, quanto à derrubada de folhas, RICHARDS (1952) assinala que as florestas tropicais apresentam grande variação entre as espécies, tornando-se difícil, as vêzes, estabelecer se essas são perenes ou caducifolias, fato observado na área da Estação Biológica de Boracéia.

POGGIANI \& MONTEIRO JÚNIOR (1990) acreditam que, tanto os períodos mais prolongados de seca como as baixas temperaturas, aceleram a derrubada de folhas em florestas do interior do estado de São Paulo.

Os dados evidenciam que a deposição de serapilheira na Estação Biológica de Boracéia, estaria mais associada às condições edafoclimáticas históricas (life-history) do ecossistema, do que às situações pontuais atípicas conforme proposto por SANTOS et al. (1984). PAGANO (1985) ao explicar a falta de correlação entre os fatores abióticos, confirma essa condição como uma forma de adaptação do ecossistema. Assim, essa afirmação concorda com a proposta de MARTINS (1979), que atribui a queda de folhas às características genéticas das espécies, que responderiam ou não, aos mecanismos 
de foto e termoperiodicidade, fatores esses assinalados, também, por ALVIM (1964); MATTHES (1980) ; MORELLATO-FONZAR (1987).

BRAY \& GOHRAM (1964) concluíram que a quantidade de material decíduo (serapilheira) está relacionada com as condições climáticas, e a deposiçào é semelhante para florestas localizadas nas mesmas latitudes, altitudes, solo, etc. Entretanto, EWEL (1976) relata uma menor deposição de serapilheira em florestas climáxicas, do que em florestas sucessionais, tendo em vista que nessas ultimas o número de espécies decíduas é maior, além da mudança constante de sua composiçào.

Autores como MEGURO et al. (1979) e SCHLITTLER (1990) também citam a possibilidade da ocorrência dessas características.

MEDWECKA-KORNAS (1971), PAGANO (1985) e SCHLITTLER (1990) salientam a necessidade de um tempo maior de amostragem em busca de correlaçòes, principalmente na faixa atlântica, entre a precipitaçào, o termo e fotoperiodismo e a deposição de serapilheira, com o objetivo de aprofundar futuros estudos dos ciclos biogeoquímicos, para melhor interpretaçào dos mecanismos que atuam no equilibrio de ecossistemas florestais. 


\subsection{TRANSFERÊNCIA DE NUTRIENTES}

A tabela 10 representa os coeficientes de correlação entre as condições climáticas e a deposição de serapilheira por fração e, em relação aos macronutrientes. Estas correlações foram não significativa a nível de $5 \%$.

Os valores médios mensais e anuais do retorno dos macronutrientes ao solo. via serapilheira, durante os dois anos do experimento, estão representados em porcentagem na tabela 11 e em kg.ha-1 na tabela 12 .

As figuras 14 e 15 representam respectivamente, as variações percentuais dos macronutrientes, em relação à pluviosidade e temperatura no decorrer dessa pesquisa. Esses dados pernitem observar que, os nutrientes N, P, $\mathrm{Ca}, \mathrm{Mg}$ e S, apresentam comportamentos semelhantes. O aumento ou a diminuição na concentração desses nutrientes, parece essar associada às variações de pluviosidade. Verificou-se que, nos meses de março, abril e dezembro, do primeiro ano, e março, abril, outubro e novembro, do segundo ano, houve aumento de pluviosidade seguido pelo aumento na concentração desses nutrientes. 
Tabela 10. Coeficiente de correlação de Pearson, entre as condições climáticas e a deposição de serapilheira e os macronutrientes.

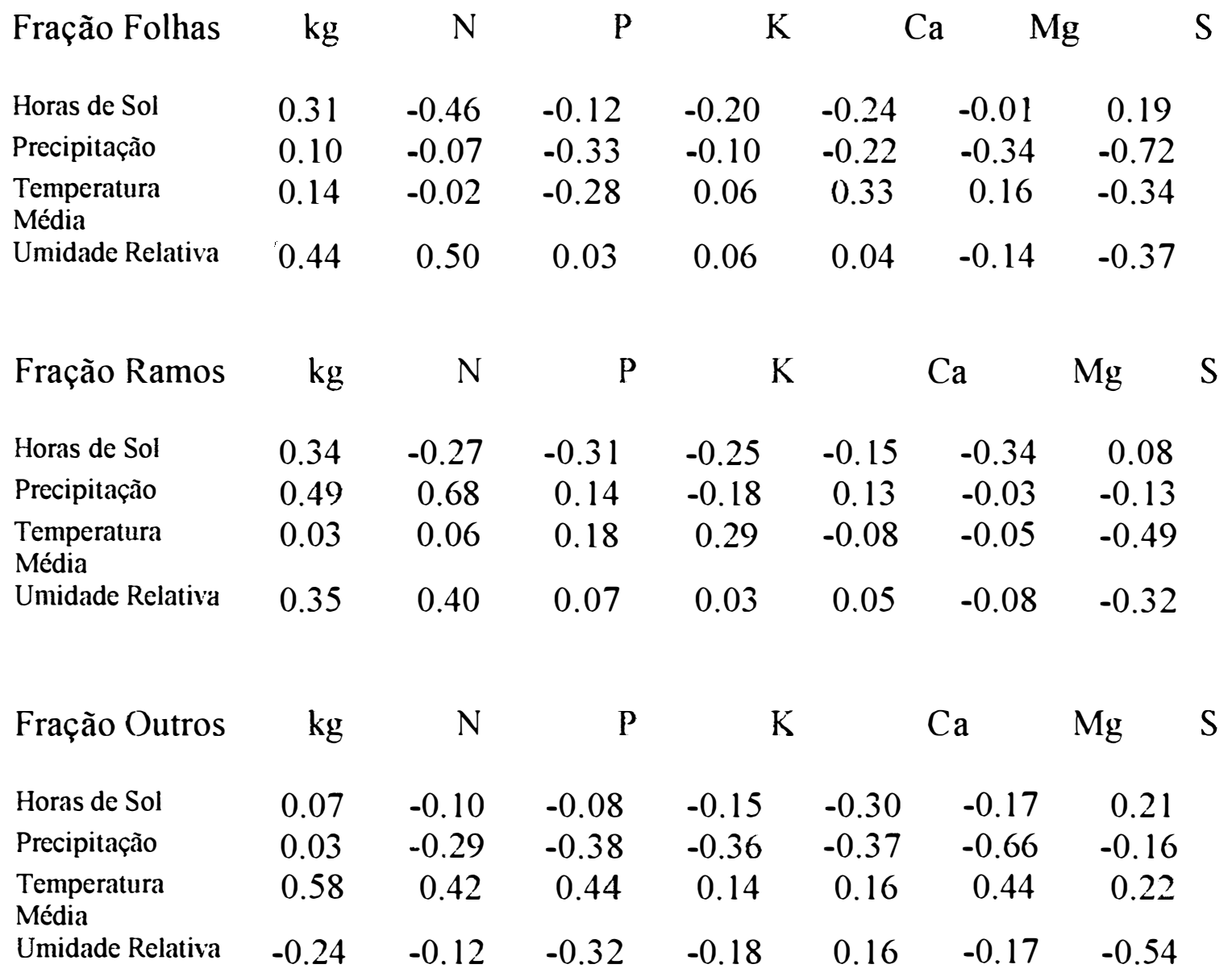


Constatou-se que, os nutrientes N, P e K apresentam-se em maiores concentrações nas frações outros, enquanto o $\mathrm{Mg}$ e $\mathrm{S}$ estão em maiores concentraçòes nas folhas, e o Ca aparece em maiores porcentagens nos ramos. A avaliação desses nutrientes em $\mathrm{kg} \cdot \mathrm{ha}^{-1}$, entretanto, evidência que as folhas constituem a fraçào que mais contribuiu para o retorno dos nutrientes ao solo, tendo em vista que o volume de material foliar decíduo é o mais expressivo.

A análise das tabelas 11 e 12 evidencia ainda que as concentraçòes dos macronutrientes apresentaram-se mais altas na fração outros, por conter fragmentos de flores, frutos e sementes.

Em geral, os valores observados situam-se, ligeiramente abaixo dos encontrados por LEITÃO FILHO et al. (1993) em três áreas da mata atlântica próximas à Cubatão. Deve-se lembrar, todavia, que a concentração de nutrientes na serapilheira está intimamente relacionada com as características edáficas e. principalmente, com a fertilidade da camada superficial do solo. 
Tabela 11.Concentração dos macronutrientes em cada fração e ano de observação.

\begin{tabular}{|c|c|c|c|c|c|c|c|}
\hline \multirow[b]{2}{*}{ ANO } & \multirow[b]{2}{*}{ ERAÇÃO } & \multicolumn{6}{|c|}{$\%$} \\
\hline & & $\mathrm{N}$ & $\mathrm{P}$ & K & $\mathrm{Ca}$ & $\mathrm{Mg}$ & $S$ \\
\hline \multirow{3}{*}{1} & Eolhas & 1,64 & 0,05 & 0,27 & 0,51 & 0,26 & 0,21 \\
\hline & Ramos & 0,33 & 0,03 & 0,18 & 0,57 & 0,17 & 0,14 \\
\hline & Outros & 0,17 & 0,11 & 0,40 & 0,50 & 0,24 & 0,20 \\
\hline \multirow{3}{*}{2} & Eolhas & 1,83 & 0,06 & 0,24 & 0,55 & 0,26 & 0,20 \\
\hline & Ramos & 1,39 & 0,04 & 0,18 & 0,59 & 0,19 & 0,15 \\
\hline & Outros & 2,05 & 0,09 & 0,29 & 0,51 & 0,25 & 0,18 \\
\hline
\end{tabular}

Tabela 12. Quantidades dos macronutrientes em cada fração e total médio dos dois anos.

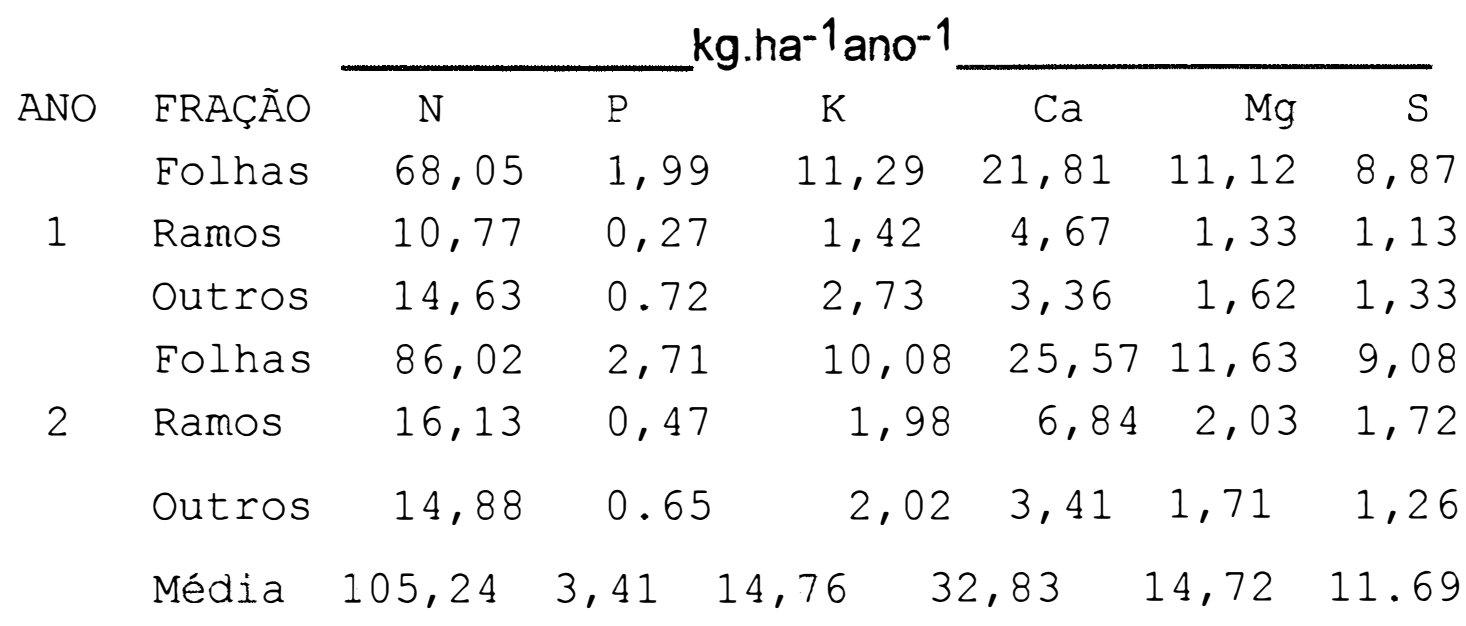



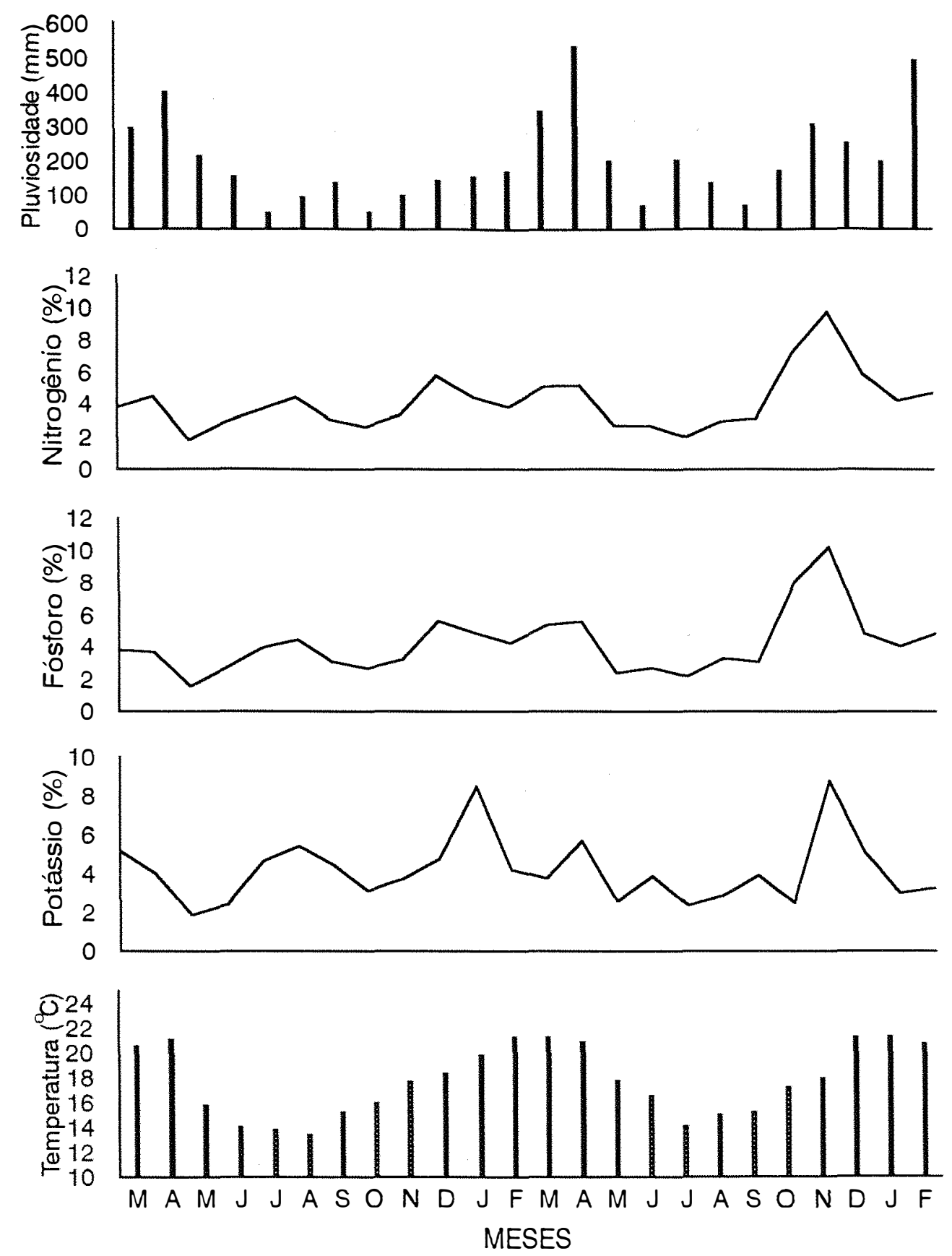

Figura 14. Variações na concentração dos nutrientes na serapilheira, ao longo do experimento, em comparação com a pluviosidade e a temperatura. 

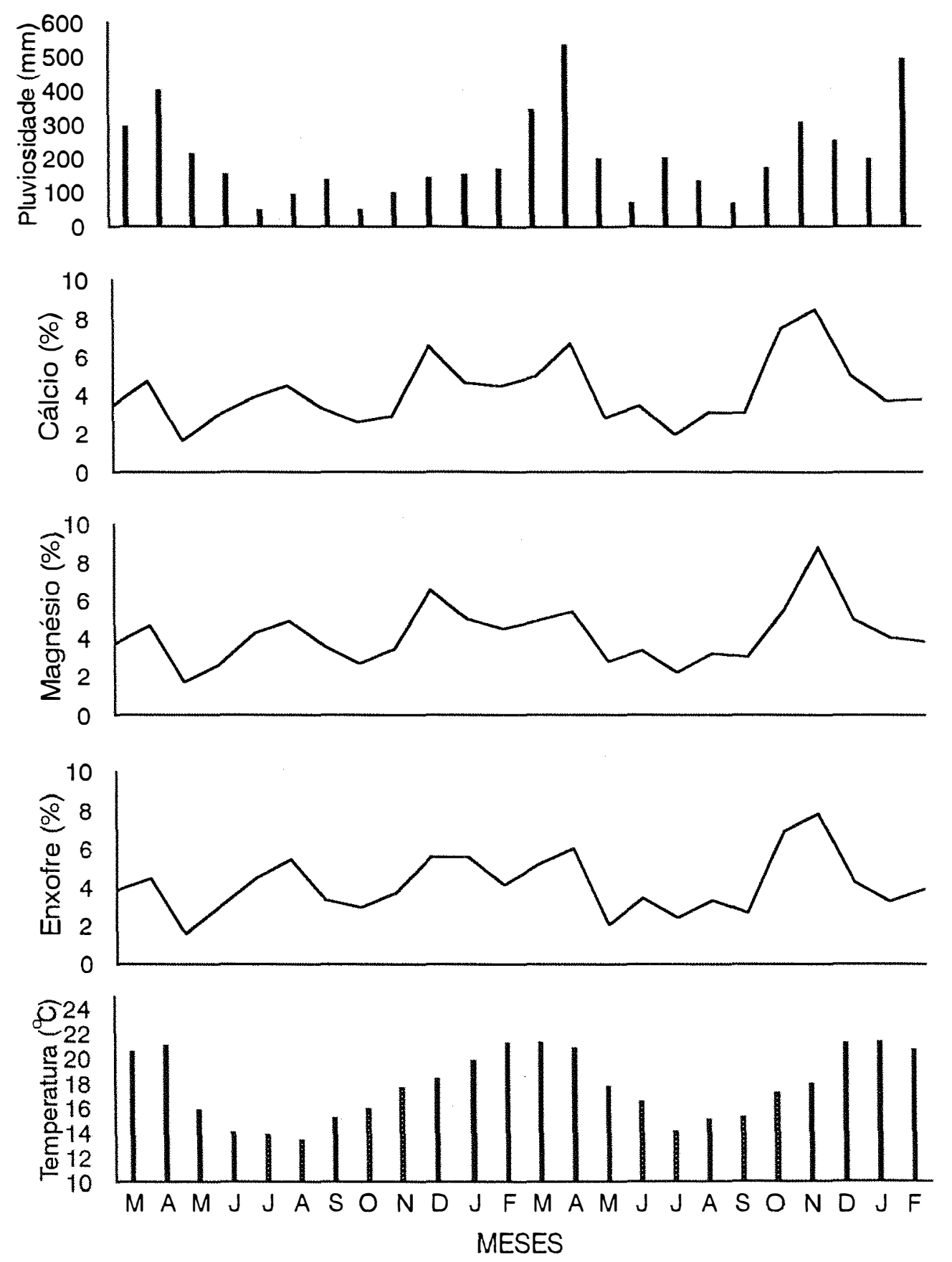

Figura 15. Variações na concentração dos nutrientes na serapilheira, ao longo do experimento, em comparação com a pluviosidade e a temperatura. 
A transferência de nutrientes da serapilheira para o solo, durante os dois anos, não apresentou grandes variações. A seqüência decrescente foi assim estabelecida $\mathrm{N}>\mathrm{Ca}>\mathrm{K}>\mathrm{Mg}>\mathrm{S}>\mathrm{P}$.

$\mathrm{O}$ retorno dos nutrientes $\mathrm{N}, \mathrm{P}, \mathrm{K}, \mathrm{Ca}$ e $\mathrm{Mg}$, observado neste estudo foi baixo se comparado a outros estudos realizados em florestas do estado de São Paulo. Entretanto, esses valores podem ser atribuídos à baixa fertilidade do solo e aos eficientes mecanismos de translocação e absorção desenvolvidos pela floresta pluvial atlântica, cuja vegetaçào restringe a perda de nutrientes como uma forma de adaptaçào à pobreza do solo e aos altos índices pluviométricos reinantes na regiào.

\subsection{SERAPILHEIRA ACUMULADA SOBRE O SOLO}

\section{E DECOMPOSIÇÃO}

Além da deposição de serapilheira, foi estudado o acúmulo de material vegetal na superficie do solo florestal, durante as quatro estações do ano. e que resultou numa média de $3.169,60 \mathrm{~kg} \cdot \mathrm{ha}^{-1}$.

A constante $(K)$ que representa a taxa instantânea de decomposição, apresentou um valor de 1,91, resultando em 0,52 anos ou 189 dias, o tempo médio de renovação, estabelecido pela formula $1 / \mathrm{K}$ segundo OLSON (1963).

O tempo médio para o desaparecimento de $50 \%$ da 
serapilheira, obtido através da equação $T_{50}=-\ln _{0,5} / K$, foi igual a 0,36 anos ou 131 dias e. o tempo necessário para o desaparecimento de $95 \%\left(\mathrm{~T}_{95}=-\ln 3 / \mathrm{K}\right)$, igual a 1,57 anos ou 573 dias (figura 16).

As constantes de decomposição $\mathrm{K}$, obtidas por diversos autores que estudaram diferentes áreas florestais do estado de São Paulo, foram: 0,86 por MEGURO et al. (1979); 1,06 por CESAR (1988); 1,15 por PAGANO (1985); 0,72 por VARJABEDIAN \& PAGANO (1988); 1,4 por DINIZ (1987); 1,02 por SCHLITTLER (1990); 0,58 por DELITTI (1984); 2,3 por POGGIANI \& MONTEIRO JÚNIOR (1990) apenas para o folhedo; 0,85, 0,72 e 0,47 por LEITÃO FILHO et al. (1993) em áreas de florestas sujeitas aos poluentes de Cubatão,SP; e 0,62 e 0,57 por VUONO et al. (1989), também em áreas afetadas por poluição no município de São Paulo.

Esses resultados demonstram que o valor da constante $\mathrm{K}$ deste estudo, é superior aos valores obtidos nos demais trabalhos realizados no estado de São Paulo, com exceção dos resultados de POGGIANI \& MONTEIRO JÚNIOR (1990), que estudaram apenas a decomposição de folhas, reconhecidas como material de rápida decomposição.

O tempo médio de desaparecimento de $50 \%$ da serapilheira, denota a rápida decomposição que ocorre na Estação Biológica de Boracéia. Esta é uma característica das florestas pluviais tropicais e subtropicais, que ainda possuem equilíbrio dinâmico e o seu ecossistema preservado.

A taxa instantânea de decomposição $(K)$, considera a relação entre a deposição de serapilheira e seu acúmulo sobre o solo. Segundo OLSON (1963), depende diretamente da temperatura, da pluviosidade e do estádio sucessional da floresta que, em clímax, apresenta-se em estado de 
equilibrio, isto é, a taxa de deposição é equivalente à taxa de decomposição (ODUM, 1986).

O desaparecimento da serapilheira observado através do material foliar remanescente, submentido à decomposição em bolsas, expressa em porcentagem do peso seco inicial, está representado na figura 16. Observa-se um rápido desaparecimento inicial, atingindo $59 \%$ nos primeiros 120 dias. Esse valor está muito próximo do valor estimado pela equação de OLSON (1963). Observase em seguida uma redução na velocidade de decomposição durante 6 meses, correspondendo ao período outono-inverno.

PAGANO (1985) e MEGURO et al. (1979) assinalam a existência de variações sazonais que afetam o processo de decomposição, as quais estão relacionadas diretamente com os fatores bióticos e abióticos. Dentre os bióticos, destacam-se principalmente, a textura das folhas e a atividade microbiológica e, dentre os abióticos, ressaltam a ação direta da pluviosidade e a da temperatura, e indireta da umidade relativa e horas de insolação. 


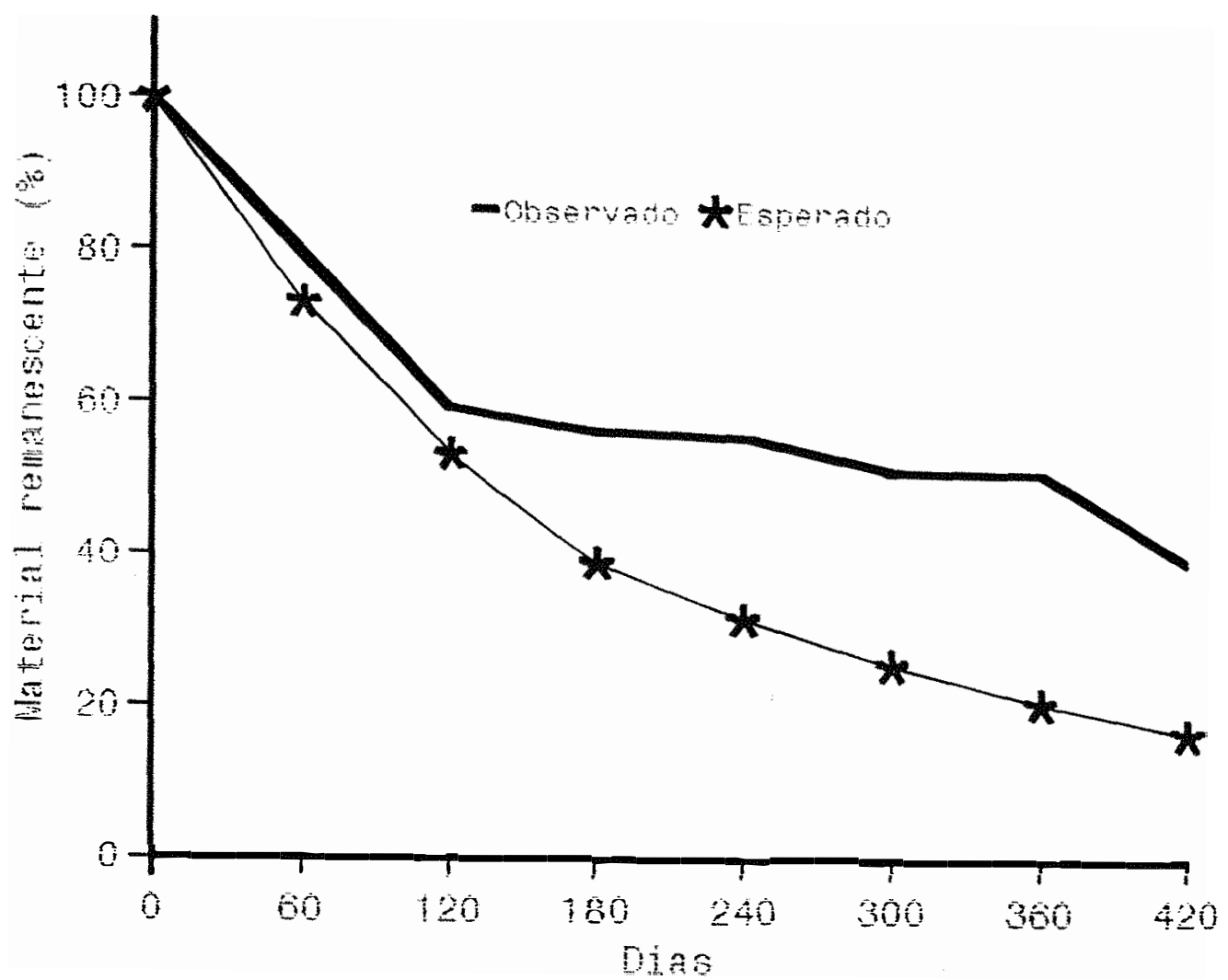

Figura 16. Representação do tempo de desaparecimento observado e do tempo esperado (segundo a equação de OLSON, 1963), da serapilheira, para a região da Estação Biológica de Boracéia/SP. To $=$ março de 1985 . 
Em geral o padrão de decomposição da serapilheira na mata atlântica, bem como nas florestas do planalto atlântico, regiões sob influência de chuvas orográficas, não apresenta variações sazonais, todavia, estudos realizados em outras florestas, do interior do estado como os de MORELLATO-FONZAR (1987); DINIZ (1987); DELITTI (1984); PAGANO (1985); CESAR (1988); SCHLITTLER (1990); POGGIANI \& MONTEIRO JÚNIOR (1990) relatam sazonalidade marcante.

Nessa pesquisa, o tempo de desaparecimento da serapilheira, estimado segundo a fórmula de OLSON (1963) e o observado experimentalmente são representados na figura 16 , que demonstram a rápida velocidade de ciclagem existente na vegetação da Estação Biológica de Boracéia, sustentada pelas condições ambientais favoráveis.

A figura 17a mostra a variação da concentração de nitrogênio, no folhedo contido nas bolsas de decomposição, que aumentou nos primeiros 4 meses, diminuindo posteriormente, e permanecendo constante até o final da observação; do fósforo, que apreşentou um ligeiro aumento em sua concentração até o $16^{\circ}$ mês e do potássio que comọ ęra esperado, devido à elevada mobilidade, apresentou uma concentração descrescente até o $8^{0}$ mês, estabilizando-se em seguida.

A figura $17 \mathrm{~b}$ representa a variação da concentração do cálcio, que apresenta um aumento nos quatros primeiros meses, voltando à concentração inicial no $12^{\circ}$ mês; do magnésio e do enxofre que apresentaram comportamento semelhante, oscilatido ao redor da concentração inicial. 
$\mathrm{O} \mathrm{P}, \mathrm{Ca}$ e $\mathrm{K}$ apresentaram comportamentos semelhantes aos relatados por MEGURO et al. (1980) e VUONO et al. (1989). Todavia, não foi observada correlação entre a concentração desses nutrientes com a variação das condições climáticas, conforme proposto por MIKOLA (1960); MEGURO et al. (1980). 

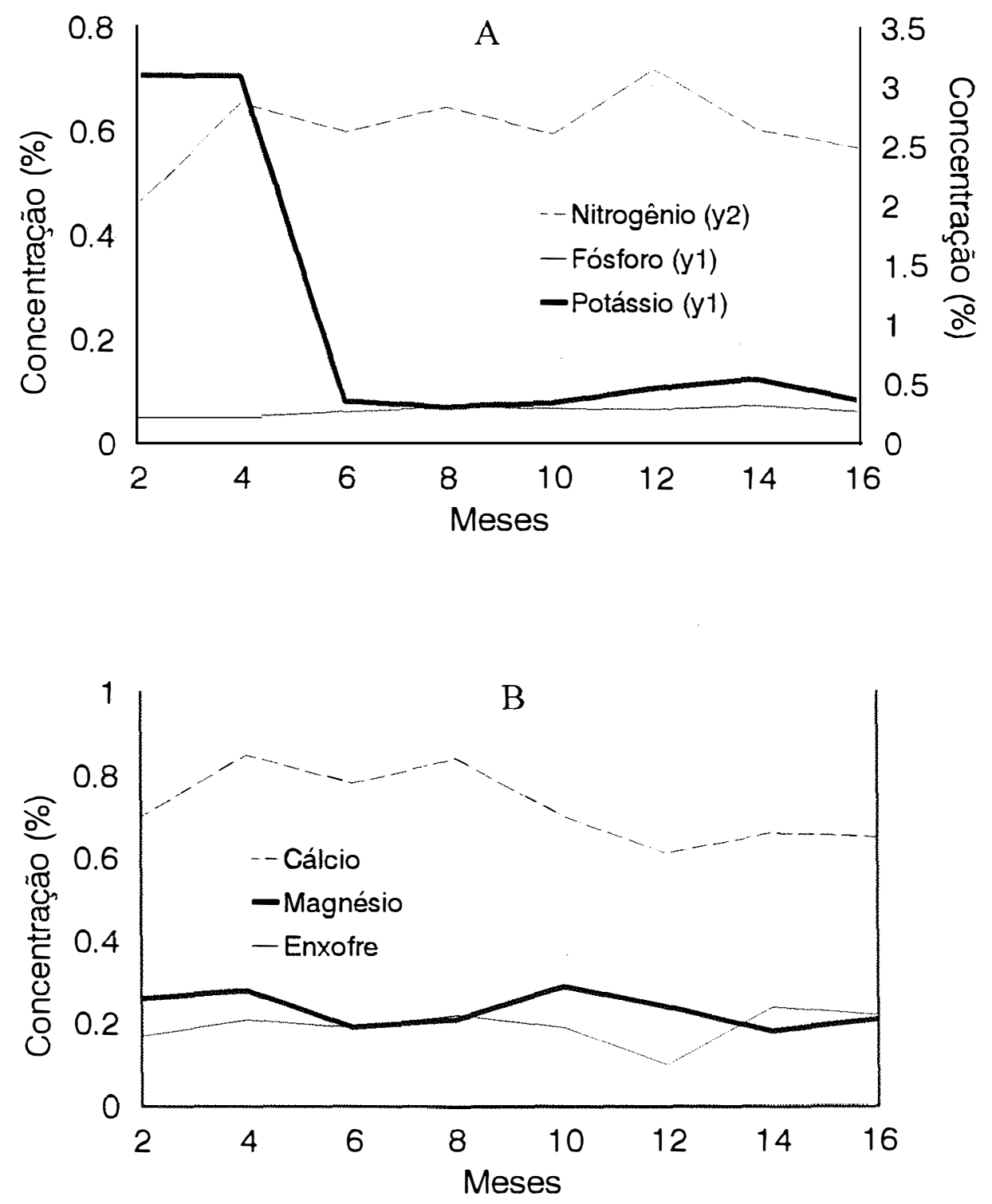

Figura 17. Variação nos teores dos macronutrientes durante a decomposiçào do folhedo, para a região da Estação Biológica de Boracéia/SP. 


\section{CONCLUSÕES}

Os resultados obtidos na avaliação da deposição e decomposição da serapilheira da vegetação na Estação Biológica de Boracéia. demonstraram que:

a. A deposição média anual de serapilheira foi de $6.054,10 \mathrm{~kg} / \mathrm{ha}$, a fração folhas contribui com 4.403,31 kg.ha-1, a fração ramos contribuiu com $974,13 \mathrm{~kg} \cdot \mathrm{ha}^{-1}$ e a fração outros contribuiu com 676,66 kg.ha-1, valores que estão um pouco abaixo dos padrões encontrados em florestas tropicais pluviais.

b. As variações ao longo do ano não evidenciaram correlacão significativa com as condições climáticas, não denotando sazonalidade marcante.

c. A fração folhas participa expressivamente da composição da serapilheira $(72,73 \%)$.

d. O retorno dos macronutrientes ao solo, acompanhou aproximadamente as oscilações de deposição de serapilheira, devolvendo em kg.ha-1.ano-1, 105,24 de N; 3,41 de P; 14,76 de K; 32,83 de Ca; 14,72 de Mg e 11,69 de S.

e. A decomposição da serapilheira em condições de campo foi mais rápida no início, face às condições climáticas reinantes (verãooutono), tornando-se mais lenta nos meses seguintes, em virtude da alteração das condições climáticas sazonais (outono-inverno).

f. A constante de decomposição $K$ foi estimada em 1,91, resultando em 0,52 anos ou 189 dias, o tempo médio de renovação da 
serapilheira. O tempo necessário para o desaparecimento de $50 \%$ e $95 \%$ da serapilheira foi, respectivamente, de 131 e $\$ 73$ dias.

g. O padrão de deposição da serapilheira na floresta pluvial atlântica na Estação Biológica de Boracéia difere do padrão observado nas florestas mesófilas do interior do Estado de São Patko que apresentam sazonalidade marcante. 


\section{REFERÊNCIAS BIBLIOGRÁFICAS}

AB'SABER, A.N. A terra paulista. Boletim Paulista de Geografia, São Paulo, 23: $5-38,1956$.

AB'SABER, A.N. A serra do mar na região de Cubatão; Avalanches de janeiro de 1985. A ruptura do equilíbrio ecológico na Serra de Paranapiacaba e a poluicão industrial. $A C J E S P$, São Paulo, 2: 74 - 116, 1987.

ALVIM, P.T. Periodicidade do crescimento das árvores em climas tropicais. In: Congresso da Sociedade Botânica do Brasil, 15, Porto Alegre, Anais 1964. p. $405-422$.

ANDRADE-LIMA, D. Vegetação. In: Instituto Brasileiro de Geografia e Estatística. Atlas Nacional do Brasil. Rio de Janeiro, IBGE. 1966.

BRASIL. Ministério da Agricultura, Comissão de solos. Levantảmento de reconhecimento dos solos do estado de São Paulo; contribuição à carta de solos do Brasil. Boletim do Serviço Nacional de Pesquisas Agronômicas, Rio de Janeiro, 12.634p. 1960.

BRAY,J.R. \& GORHAM, E. Litter production in forests of the world. Advances in Ecological Research, London, 2: 101 - 157, 1964. 
CAMPOS, G. Mappa florestal. Ed Typ. da Diretoria do Servico de Estatística. Rio de Janeiro, 1912. 102p.

CARPANEZZI, A.A. Produção de material orgânico e nutrientes em uma floresta natural e em uma plantação de Eucaliptus no interior do estado de São Paulo. Piracicaba, 1980. 107p. (Mestrado-ESALQ/USP).

CESAR, O. Composição florística, fitossociologia e ciclagem de nutrientes em mata mesófila semidecídua (Fazenda Barreiro Rico. Mun. Anhembi (SP). Rio Claro, 1988. 222p. (Livre-Docência - Universidade Estadual Paulista).

COUTINHO, L.M. Contribuição ao conhecimento da Ecologia da Mata Pluvial Tropical. Boletim da Faculdade de Filosofia Ciências e Letras da Universidade de São Paulo, 257p (Botânica). 1962.

CUSTODIO FILHO, A. Flora da Estação Biológica de Boracéia - Listagem de espécies. Revista do Instituto Florestal, São Paulo, 1(1): 161 - 199, 1989.

DELITTI, W.B.C. Aspectos comparativos da ciclagem de nutrientes minerais na mata ciliar, no campo cerrado e na floresta implantada de Pinus elliottii Englem. var. elliottii (Mogi-Guaçu, S.P.). São Paulo, 1984. 298p. (Doutoramento - USP).

DINIZ, S. Ciclagem de nutrientes associados aos processos de producão e decomposicão do folhedo em um ecossistema de mata mesófila semidecídua, no município de Araras - Rio Claro. 1987. 89p. (Mestrado UNESP/Rio Claro). 
DOMINGOS, M.; POGGIANI, F.; VUONO, Y.S. \& LOPES, M.I.M.S. Producão de serapilheira na floresta da Reserva Biológica de Paranapiacaba, sujeita aos poluentes atmosféricos de Cubatão. Hoehnea, São Paulo, 17(1): 47 - 58, 1990.

EWEL, J.J. Litter fall and leaf decomposition in a tropical forest succesion in Eastern Guatemala, Journal of Ecologv, 64: 293 - 308, 1976.

FERRI, M.G. Ecologia, temas e problemas brasileiros. Belo Horizonte, Editora Itatiaia e Editora da Unversidade de São Paulo. 1974.188p

FERRI, M.G. Vegetação brasileira. Belo Horizonte, Itatiaia, 1980. 157p.

GARRIDO, M.A.O. Caracteres silviculturais e conteúdo de nutrientes no folhedo de alguns povoamentos puros e mistos de espécies nativas. Piracicaba. 1981. 105p. (Mestrado - ESALQ/USP)

GOLLEY, F.B.; McGINNIS, J.T.; CLEMENTS, R.G.; CHILD,G.I. \& DUERVER, M.J. Ciclagem de minerais em um ecossistema de floresta tropical úmida, São Paulo, EPU/EDUSP, 1978. 256p.

GOSZ, J.; LIKENS, G.E. \& BORAMANN, F.H. Nutrients content of litter fall on the hubbard brook experimental forest, New Hampshire. Ecology, 53(5): $769-784,1972$.

HOLDRIDGE, L.R. Ecologia hasada en zonas de vida. Editora de La Serie: Matilde de La Cruz M. 1978. 216p 
HOPKINS, B. Vegetation of the Olokomeji forest Reserve (Nigeria). IV - the litter and soil with special reference to their sazonal changes. Journal of Ecology, London, 54(3): 687 - 703, 1966.

HUECK, K. Problemas e importância prática da fitossociologia no estado de São Paulo. (Contribuicũo para a pesquisa fitossociológica paulista), São Paulo, Instituto de Botânica, 18p. 1953.

JACKSON, J.F. Seasonality of flowering and leaf-fall in a Brazilian Subtropical Lower Montane Moist forest. Biotropica, 10(1): 38 - 42, 1978.

JOLY, A.B. Conheça a vegetaçũo brasileira. São Paulo, EDUSP, 1970. 181 p.

KIMMINS, J.P. Forest Ecology, New York. MacMilland Published Co. 532 pg. 1987.

KLINGE, $\mathrm{H}$. Fine litter production on nutrient return to the soil in three natural forest stand of eastern Amazonia. Tropical Ecology. 20(2): 225 - 235, 1977.

KLINGE, H. \& RODRIGUES, W.A. Litter production in an area of Amazonian terra firme forest. Part I. Litter fall, organic carbon and total nitrogen contents of litter. Amazoniana, Manaus, 1(4): 287 - 302, 1968 a.

KLINGE, H. \& RODRIGUES, W.A.. Litter production in an area of Amazonian terra firme forest. Part II. Mineral nutrient content of the litter. Amazoniana, Manaus, 1(4): 303 - 310, 1968b.

KOEPPEN, W. Climatologia. 1948. Mexico, Ed. Fondo de la Cultura Economica. 253p. 
LEITÃO FILHO. H.F. Aspectos taxonômicos das florestas do estado de São Paulo. Silvieultura em São Paulo, São Paulo, 16(1): 197 - 204, 1982.

LEITÃO FILHO, H.F. Consideraçòes sobre a florística de florestas tropicais e sub-tropicais do Brasil. IPEF, Piracicaba. 35: 41 - 46, 1987.

LEITÃO FILHO. H.F; PAGANO, S.N.; CESAR, O.; TIMONI, J.L. \& RUEDA, J.J. Ecologia da Mata Atlântica em Cubatão (SP). editora UNESP e editora UNICAMP. 1993. 184p.

LONSDALE, W.M. Predicting the amount of litterfall in Forest of the word. Annals of Batany, 61:319 - 324,1988.

LUIZÃO, F.J. Produção e decomposição da liteira em floresta de terra firme da Amazônia Central. Aspectos químicos e biológicos da lixiviação dos nutrientes da liteira. Piracicaba. 1982. 90p.

MARTINS, F.R. O método de quadrantes e a fitossociologia de uma floresta do interior do Estado de São Paulo: Parque Estadual de Vassununga. São Paulo, 1979. 239p. (Doutorado - USP).

MASON, C.F. Decomposicão, São Paulo, EDUSP, 1980. 63p.

MATTHES, L.A.F. Composiçâo florística, estrutura e fenologia de uma floresta residual do planalto paulista: bosque dos jequitibás. (Campinas/SP). Campinas. 1980. 209p. (Mestrado UNICAMP). 
MATTOS FILHO, B. A "Estação Biológica do Alto da Serra" sob o prisma metereológico. Archivos do Instituto Biológico. São Paulo, 3: 109 - 127, 1930.

MEDWECKA-KORNAS, A. Plant litter. In: Phillpson, J. Ed. Methods of study in quantitative soil Ecology: Population, production and energy flow. Oxford, Blackuell Scientific Publication. 24 - 33 p. 1971.

MEGURO, M. Ciclagem de nutrientes minerais nos ecossistemas da Mata Atlântica: alguns aspectos. $A C I E S P, 54: 98$ - 122, 1987.

MEGURO, M.; VINUEZA, G.N. \& DELITTI, W.B.C. Ciclagem de nutrientes minerais na mata secundária - São Paulo: 1 - producão e conteúdo de nutrientes minerais no folhedo. Boletim de Botânica, São Paulo, 7: 61 - 67, 1979.

MEGURO, M.; VINUEZA, G.N. \& DELITTI, W.B.C. Ciclagem de nutrientes minerais na mata secundária - São Paulo: III - Decomposição do material foliar e liberação dos nutrientes minerais. Boletim de Botânica, São Paulo, 8: 7 - 20, 1980.

MIKOLA, P.M. Comparative experiment on decomposition rates of forest litter in southern and northern Finland. Oikos, 11(1): 161 - 166, 1960.

MORRELATO-FONZAR, L.P.C. Estudo comparativo de fenologia e dinâmica de duas formações florestais na Serra do Japi, Jundiaí. SP. Campinas, 1987. 232p. (Mestrado -UNICAMP). 
MUELLER-BOMBOIS, D. \& ELLENBERG, H. Aims and methods of vegetation ecology. John Willey \& Sons Co, New York, 545p. 1974.

NIMER, E. Climatologia do Brasil. Rio de Janeiro, SUPREN/IBGE, 1979. 421p.

ODUM, E.P. 1986 Ecologia. Rio de Janeiro. Ed. Guanabara. 431 p.

OLSON, J.S. Energy storage and the balance of producers and decomposers in ecological systems. Ecology, 44(2): 322 - 331, 1963.

PAGANO, S.N. Estudo florístico, fitossociológico e de ciclagem de nutrientes em mata mesófila semidecídua, no município de Rio Claro, Rio Claro, 1985. 201p. (Livre Docência - UNESP).

POGGIANI, F. Ciclo de nutrientes e produtividade de floresta implantada. Silvicultura, São Paulo, 1(3): 45 - 48, 1976.

POGGIANI, F. \& MONTEIRO JÚNIOR, E.S. Deposicão de folhedo e retorno de nutrientes ao solo numa floresta estacional semidecidua, em Piracicaba, estado de São Paulo. In: Congresso Florestal Brasileiro. 60, São Paulo, Anáis 1990. 596 - 602.

POGGIANI, F.; COUTO, H.T.Z. \& SIMÕES, J.W. Aspectos ecológicos das mini-rotações e aproveitamento dos resíduos florestais. Circular Técnica IPEF, Piracicaba, 74:1 - 7, 1979.

PONÇANO, W.L.; CARNEIRO, C.D.R.; BISTRICHI, C.A.; ALMEIDA, F.F.M. 
\& PRANDINI, F.L. Mapa geomorfológico do estado de São Paulo. IPT. 1981.v.2.

RICHARDS, P.W. The tropical rain forest. London, Cambridge Univ. Press. 450p. 1952.

RIZZINI, C.T. Tratado de fitogeografia do Brasil. São Paulo. Hucitec/EDUSP. 1979. v.2.

RIZZO, J.A.: CENTENO, A.J; SANTOS, J.S. \& FILGUEIRAS, T.S. Levantamento de dados em áreas de cerrado e da floresta caducifolia tropical do planalto centro-oeste. In: III Simpósio sobre o cerrado. 103-109. 1971.

ROMARIZ, D.A. A vegetação. In: Brasil - a terra e o homem. as bases físicas São Paulo, Cia. Editora Nacional. 1972. p. 521 - 550.

SANTOS, P.F.; ELKINS, N.Z.; STEINBERGER, Y. \& WHITFORD, W.G. A comparison of surface and buried Larrea tridentata leaf litter decomposition in North American hot deserts. Ecology, 65(1): 278 - 284,1984

SCHLITTLER, F.H.M. Fitossociologia e ciclagem de nutrientes na floresta tropical do Parque Estadual do Morro do Diabo (região do Pontal do Paranapanema, estado de São Paulo). 1990. 279p. ( Doutoramento, Rio Claro - UNESP).

SETZER. J. Contribuição para o estudo do clima do estado de São Paulo, São Paulo, Escolas Profissionais Salesianas, 239p. 1946. 
SHANKS, R.E. \& OLSON, J.S. First-year breakdown of leaf litter in Southern Appalachian forest. Science. 134: 194 - 195, 1961.

SILVA, M.F.F. Produção anual de serrapilheira e seu conteúdo mineralógico em mata tropical de terra firme, Tucuruí-PA. Boletim Museu Paraense Emilio Goeldi, Botânica, 1(1/2): $111-58,1984$.

SILVA, A.F. \& LEITÃO FILHO, H.F. Composição florística e estrutura de um trecho de mata atlântica de encosta no município de Ubatuba (São Paulo, Brasil). São Paulo. Revista Brasileira de Botânica. São Paulo, 5(1/2): 43 $52,1982$.

SILVA, M.F.F. \& LOBO, M.G.S. Nota sobre produção de matéria orgânica em floresta de terra firme. várzea e igapó. Boletim Museu Paraense Emilio Goeldi, Belem, 56: 1 - 13, 1982.

TEIXEIRA, C.B.; DOMINGOS, M.; REBELO, C.F. \& MORAES, R.M. Producão de serapilheira em floresta residual da cidade de São Paulo: Parque Estadual das Fontes do Ipiranga. Revista do Instituto Florestal, São Paulo, 4:785 - 789, 1992.

VARJABEDIAN, R. \& PAGANO, S.N. Produção e decomposicăo de folhedo em trecho de Mata Atlântica de encosta no município do Guarujá, SP. Acta Botânica Brasilica, 1(2): 243 - 256, 1988.

VELOSO, H.P. \& KLEIN, R.M. As comunidades e associacões vegetais da mata pluvial do sul do Brasil. I. As comunidades do município de Brusque, estado de Santa Catarina. Sellowia, ltajaí, 9: 81 - 235, 1957. 
VUONO, Y.S.; DOMINGOS, M. \& LOPES, M.I.M.S. Decomposição da serapilheira e liberação de nutrientes na floresta da Reserva Biológica de Paranapiacaba, sujeita aos poluentes atmosféricos de Cubatão, São Paulo, Brasil. Hoehnea, São Paulo, 16: 179 - 193, 1989.

VUONO, Y.S.; LOPES, M.I.M.S \& DOMINGOS, M. Poluicão atmosférica e nutrientes tóxicos na Reserva Biológica do Instituto de Botànica, São Paulo, Brasil. Revista Brasileira de Botânica. 7(2): 149 - 156, 1984.

WALTER, H. Vegetacão e zonas climáticas: tratado de ecologia global. Ed. Pedagógica e Universitária, São Paulo. 325p. 1984.

WALTER, H. Vegetation of the Earth in relation to climate and the ecophysiological conditions. Spring-Verlag, New York, 237p. 1977.

WETTSTEIN, R.R.V. Plantas do Brasil, aspectos da vegetação do Sul do Brasil. São Paulo, EDUSP/Edgard Blucher Ltda. 126p. 1970.

ZAGATTO, E.A.G.; JACINTHO, A.O.; REIS, B.F.; KRUG, F.J.; BERGAMIN FILHO, H.; PESSENDA, L.C.R.; MORTATTI, J. \& GINE, M.F. Manual de análise de plantas e águas empregando sistemas de injeção em fluxo CENA. USP, 45p. 1981. 